\title{
Jânio Quadros: genealogia e conexões paranaenses
}

\author{
Ricardo Costa de Oliveira ${ }^{1}$ \\ Mônica Helena Harrich Silva Goulart ${ }^{2}$
}

RESUMO: O presente artigo investiga os passos da família de Jânio Quadros no Paraná, seus principais representantes nas figuras de seu pai, avô, tios, tias e primos. Para tanto, as fontes obtidas pela Hemeroteca, no site da Biblioteca Nacional foram fundamentais no que tange ao levantamento das várias informações biográficas, dispersas em variados periódicos e que formaram o centro de nossa composição documental. Na mesma relevância, o livro de Bernardo Schmidt (2012) sobre a biografia de Jânio Quadros. Também nos utilizamos de obras e pesquisas já realizadas pelo NEP - Núcleo de Estudos Paranaenses. As informações disponíveis no site do Arquivo Público sobre as secretarias de Governo no período de 1928, 1929 e 1930 também foram significativas, embora pouco se obteve em termos de resultado institucional, ou seja, poucos Quadros tiveram altos cargos públicos no Paraná, apesar de serem uma família com certo "status social" e terem suficientes capitais sociais e políticos.

Palavras-chave: Jânio Quadros, Genealogia, família, Paraná.

\section{Jânio Quadros: genealogy and paranaenses connections}

\begin{abstract}
This article investigates the steps of the family of Jânio Quadros in Paraná, his main representatives in the figures of his father, grandfather, uncles, aunts and cousins. To that end, the sources obtained by the Hemeroteca, on the site of the National Library, were fundamental in relation to the survey of the various biographical information, dispersed in various periodicals and that formed the center of our documentary composition. In the same relevance, the book by Bernardo Schmidt (2012) on the biography of Jânio Quadros. We also use works and research already carried out by NEP - Núcleo de Estudos Paranaenses. The information available on the Public Archive website about the government secretariats in the period of 1928, 1929 and 1930 was also significant, although little was obtained in terms of institutional results, that is, few staff had high public positions in Paraná, despite being a family with a certain "social status" and sufficient social and political capital.
\end{abstract}

Key Words: Jânio Quadros, Genealogy, Family, Paraná.

\section{Introdução}

\footnotetext{
${ }^{1}$ Doutor em Ciências Sociais, Professor de Sociologia da Universidade Federal do Paraná, UFPR, Programa de Pós-Graduação em Sociologia.

${ }^{2}$ Doutora em Sociologia, Professora na Universidade Tecnológica Federal do Paraná, UTFPR-DAESO. Professora Colaboradora no Programa de Pós-Graduação em Sociologia, na Universidade Federal do Paraná, UFPR.
} 
Revista NEP, Núcleo de Estudos Paranaenses, Curitiba, v.4, n.2, dez. 2018

A família de Jânio Quadros representa mais um dos exemplos típicos de grupos que obtiveram capitais sociais e políticos importantes para se manterem em posições importantes ao longo do tempo e de várias gerações. No Paraná, os Quadros, sobretudo os tios e tias de Jânio, conseguiram assegurar bons matrimônios e também acumularam formação superior entre seus membros, haja vista Gabriel de Quadros, pai de ex presidente da República, que conseguiu acumular três profissões ao mesmo tempo, sendo técnico engenheiro agrônomo, farmacêutico e médico.

$\mathrm{Na}$ política, ainda que não se encontrando no centro do poder, os Quadros também se estabeleceram com vínculos partidários ainda no contexto da República Velha. Vale salientar que, dentre vários aspectos que se pode percorrer quando buscamos a linha genealógica de uma família, os Quadros possuem a "marca" da violência em seus itinerários, seja estabelecendo conflitos com outros grupos e até mesmo entre o referido clã. Assim, o caso de maior confronto entre os Quadros ocorreu no embate político com Manoel Ribas, então interventor no Paraná.

O presente artigo, portanto, denota pontuar os passos da família de Jânio Quadros no Paraná, seus principais representantes nas figuras de seu avô, pai, tios, tias e primos. Para tanto, as fontes obtidas pela Hemeroteca, no site da Biblioteca Nacional foram fundamentais no que tange ao levantamento das várias informações biográficas, ainda que dispersas em variados periódicos, formaram o centro de nossa composição documental. Na mesma relevância, o livro de Bernardo Schmidt (2012) sobre a biografia de Jânio Quadros. Também nos utilizamos de obras e pesquisas já realizadas pelo NEP Núcleo de Estudos Paranaenses. As informações disponíveis no site do Arquivo Público sobre as secretarias de Governo no período de 1928, 1929 e 1930 também foram significativas, embora pouco se obteve em termos de resultado institucional, ou seja, poucos Quadros tiveram cargos públicos no Paraná. Contudo, o traçar genealógico se faz a partir de um olhar crítico das conexões e itinerários dos agentes investigados, para tanto, o fazer sociológico só pode ser conduzido quando pensado a partir das relações sociais, de suas estruturas e instituições.

\section{Jânio Quadros}


Revista NEP, Núcleo de Estudos Paranaenses, Curitiba, v.4, n.2, dez. 2018

Personagem importante da história política e republicana do Brasil, seu nome perpassa aspectos controversos do jogo político no executivo federal e regional. Jânio da Silva Quadros protagonizou um dos momentos eleitorais mais emblemáticos e contundentes que tiveram como mote principal o combate à corrupção e, também, ao renunciar inesperadamente seu mandato de presidente após sete meses de exercício, em 1961. (JÂNIO, 2018).

Proveniente de um sobrenome paterno com laços genealógicos ${ }^{3}$ no Paraná pouco se tem dito sobre as raízes e conexões de Jânio Quadros no Paraná. Dentre as relações estabelecidas, a genealogia de Quadros estreitou laços por via de matrimônio com outras famílias paranaenses importantes, tais como Lupion, Ribeiro, Slaviero, Camargo e Leprevost.

Embora Jânio Quadros tenha nascido em Campo Grande, Mato Grosso do Sul, em 25 de janeiro de 1917, seu pai, Gabriel Nogueira de Quadros, era natural do estado do Paraná, de Piraquara. Sua mãe, Leonor da Silva Quadros (filha do transportador de gado e major Ruffo ${ }^{4}$ Silvano da Silva, de origem argentina e de Edwirges Vergínea Marques de Góes Silvano da Silva ${ }^{5}$ - que teve apenas o irmão Eurípedes da Silva e as irmãs: Eurípedes da Silva, Edwirges da Silva- que seria a sogra de Affonso Alves de Camargo Junior - e Fidelina que fora casada com Antonio Vendas ), era do Mato Grosso. Gabriel e Leonor, chamada de Liúde, se casaram em 10 de julho de 1915, na casa de seus pais. Jânio teve apenas uma irmã, Dirce Maria Quadros, nascida em 22 de maio de 1919 e falecida em novembro de 1934. O primeiro filho de seus pais nasceu morto, ainda em Miranda, no ano de 1916. (DATAS, 1930; SENHORINHA, 1934; SCHMIDT, 2012). Jânio casou-se com Eloá do Vale e teve a filha Dirce Maria do Valle Quadros, nome escolhido em homenagem à sua irmã.

\footnotetext{
${ }^{3}$ Importante destacar que “(...)o sobrenome Quadros vem de antiga família, já existente na Espanha em 1248 e erradicada no Brasil desde 1599. Foi quando veio povoar a capitania de São Vicente, o fidalgo espanhol de Sevilla, Bernardo de Quadros [faleceu no Brasil em 1642] casado com Cecília Ribeiro Baião, portuguesa nascida em Beja [em 1602 e falecida no Brasil em 1667], dos quais se originaram a maioria absoluta da família Quadros ou de Quadros." (GOMES, 2014).

${ }^{4}$ Ruffo, avô materno de Jânio, era argentino, de Córdoba. A avó, Edwirges (nome também encontrado na grafia Eduvirges), era do Mato Grosso, de Miranda - com ascendência índia. (SCHMIDT, 2012).

${ }_{5}^{5}$ Filha de Joaquim Antonio de Góes e Balbina Marques de Góes, ambos de Miranda, Mato Grosso. (SCHMIDT, 2012).
} 
Revista NEP, Núcleo de Estudos Paranaenses, Curitiba, v.4, n.2, dez. 2018

No que diz respeito a sua trajetória política ${ }^{6}$, Jânio da Silva Quadros, bacharel em Direito, disputou seu primeiro cargo eletivo em 1947, para vereador. Neste pleito não obteve votos suficientes para assumir uma cadeira na Câmara Municipal de São Paulo, porém, com a cassação do Partido Comunista do Brasil e, portanto, de seus representantes, acabou assumindo o parlamento em 1948, como suplente. (JÂNIO, 2018).

Como resultado da projeção que teve na câmara municipal, elegeu-se em 1950 para a Assembleia Legislativa de São Paulo. Neste mandato, desenvolveu sua bandeira de "moralização da política e do serviço público" ao percorrer todo interior do estado, fato que foi decisivo para promover sua vitória eleitoral, pelo PDC (Partido Democrata Nacional) em coligação com o PSB (Partido Socialista Brasileiro), quando disputou a prefeitura de São Paulo, em 1953. “Assumiu a prefeitura aos 36 anos, e um dos seus primeiros atos foi promover demissões em massa de funcionários, iniciando uma cruzada moralizadora que marcou sua gestão.” (JÂNIO, 2018).

Em 1954 renunciou a prefeitura para candidatar-se ao governo do estado, vencendo as eleições. Assumiu o executivo estadual em janeiro de 1955. As conexões políticas de Jânio e a significativa influência dos Quadros proporcionaram sua vitória eleitoral no Paraná quando disputou o cargo de deputado federal, pelo $\mathrm{PTB}^{7}$ (Partido Trabalhista Brasileiro), ainda que fosse do Mato Grosso. No ano de 1959, o Movimento Popular Jânio Quadros (MPJQ) lançou a campanha de Jânio para a disputa presidencial da República. Em 3 de outubro de 1960 venceu as eleições presidenciais, assim como João Goulart elegeu-se vice-presidente. Poucos meses depois, a 25 de agosto de 1961 Jânio Quadros renunciou à presidência da República. Após derrotas eleitorais, em 1985 venceu novamente as eleições para prefeitura de São Paulo, pelo PTB (pleito no qual derrotou Fernando Henrique Cardoso), concluindo seu mandato em 1988. Jânio faleceu em São Paulo, no dia 16 de fevereiro de 1992.

\section{As raízes paranaenses}

\footnotetext{
${ }^{6}$ Não pretendemos aqui traçar a biografia de Jânio Quadros, mas tão somente apontar brevemente sua trajetória política. Para uma análise mais detalhada, vale os seguintes autores: BENEVIDES, 1981; CHAIA, 1991; FERREIRA, DUARTE,2011; BRANCO, 1996; SCHMIDT, 2012. Entre outras obras, artigos, teses de doutorado e dissertações de mestrado.

${ }^{7}$ Inclusive Jânio foi o deputado mais votado no Paraná, aos 41 anos de idade, com 78.810 votos. (BATISTELLA, 2017, p. 198).
} 
Revista NEP, Núcleo de Estudos Paranaenses, Curitiba, v.4, n.2, dez. 2018

Seu pai, Gabriel Nogueira de Quadros, nasceu em Piraquara, no dia 9 de março de 1892. Filho do capitalista e coronel João Manoel de Quadros e de Ana Avelina Nogueira. João, avô de Jânio, foi presidente da Vila de Campina Grande do Sul, no período de 7 de janeiro de 1887 a 7 de janeiro de 1888, o primeiro cargo político assumido pela família Quadros no estado do Paraná. João faleceu em 1913. (A REPÚBLICA, 1926; MISSA, 1913).

O bisavô do Jânio foi Manoel Joaquim de Quadros, nascido entre 1830 a 1837, foi professor em Barra Velha, Santa Catarina, subdelegado, casado com Maria Clara da Siqueira $^{8}$, falecida em Curitiba, em junho de 1910 com 94 anos, ambos do Litoral de Santa Catarina. (AGRADECIMENTO, 1910; A REPÚBLICA, 1926). Aos 50 anos de idade, Manoel vivia em Santa Catarina, era elegível, sabia ler e possuía renda de $\$ 400$. Filho de Joaquim José de Quadros ${ }^{9}$, trisavô de Jânio. Do casal Manoel Joaquim e Maria Clara, encontramos os seguintes filhos: Maria Philippa Quadros (casada com Manoel Nunes Pereira), Serafina de Quadros da Luz (casada com Bento Gonçalves da Luz), João Manoel de Quadros (avô de Jânio), Antonio Manoel de Quadros. Nesta lista, segundo Schmidt (2012), faltam os irmãos Zepherino e Carlotta. Manoel Joaquim de Quadros, Zeferino do Nascimento Quadros e Serafina Maria de Nazareth Quadros foram professores no Norte de Santa Catarina ${ }^{10}$.

Sobre o trisavô de Jânio, Joaquim José de Quadros, também encontramos a indicação de que fora prisioneiro de guerra pelo exército paraguaio em 1868, na condição de cabo de esquadra da Província de Santa Catarina, durante a Guerra do Paraguai, na referida nota do jornal Dezenove de Dezembro, do dia 16 de janeiro de 1869, caso não

\footnotetext{
${ }^{8}$ Diário da Tarde, Curitiba, 27/ 06/1910, página 2. A República, Curitiba, 16/03/1907, página3. Gazeta de Joinville, 4 /6/1878. Disponível em: <http://www.memoriaitaperiuense.com.br/2010/09/familiamacaneiro.html $>$. Acesso em: novembro de 2018.

${ }^{9}$ Consta no jornal A Regeneração, jornal da Província de Santa Catarina, na data de $1^{\circ} \mathrm{dez} .1878$ a seguinte nota: "340 - Manoel Joaquim de Quadros, 41 anos, casado, lavrador, sabe ler, filho de Joaquim José de Quadros, renda presumida 200\$; simples votante.” Grifo nosso. Indicamos que a informação se refere à lista de eleitores qualificados votantes na paróquia da SS. Trindade, pela junta municipal da capital, Cidade de Desterro (JUNTA, 1878). Novamente é listado no jornal - A Regeneração. 8/8/1880. 50 anos em 1880. Elegível. Suplemento.

${ }^{10}$ O Despertador. 15 de maio de 1875.
} 
Revista NEP, Núcleo de Estudos Paranaenses, Curitiba, v.4, n.2, dez. 2018

seja um homônimo da mesma época, o que pode ocorrer em pesquisas genealógicas com poucas fontes sobreviventes do passado:

\begin{abstract}
"Prisioneiro - Apresentou-se ontem ao Em. Sr. presidente da província o cabo de esquadra da extinta companhia de cavalaria desta província Joaquim José de Quadros, que, segundo diz, achando-se adido ao $1^{\circ}$ regimento de artilharia a cavalo em Tuyuty foi, no reconhecimento [Fortaleza] de Humaitá, extraviado e prisioneiro pelos paraguaios. Sendo levado para uma povoação muito além da Encarnação, onde se demorou em serviço uns quinze dias mais ou menos, em uma noite tempestuosa logrou evadir-se o sertão que vem ter ao rio Paraguai; aí chegando atirou-se n'água com o auxílio de um pau que tomou como - salva vidas - nadou mais de 24 horas para o lado da província de Corrientes, demorou-se 18 dias em uma ilha deserta, cujo nome ignora, e atirando-se de novo à água nadou por muito tempo; seguiu depois pelas cabeceiras do Aguapehy, alcançando os ervais da fronteira de Corrientes com esta província; esteve no erval de Pedro Pagy; seguiu depois pelo sertão da fronteira e veio sair no campo Erê, distrito de Palmas, deixando o rio Iguaçu a esquerda e o Uruguai à direita. Gastou em todo esse trajeto unicamente dois meses." (NOTICIÁRIO, 1869).
\end{abstract}

Antonio Manoel de Quadros, tio avô paterno de Jânio, nasceu em 15 de fevereiro de 1849 e faleceu em 20 de janeiro de 1915. Entre os anos 1870 a 1890 foi tabelião de notas na Vila de São José, além de coronel da Guarda Nacional. Casou-se em 1875 com Maria Elisa Scharffenberg, nascida em 17 de setembro de 1857, em Hamburgo, na Alemanha, e falecida em 2 de fevereiro de 1912 em Curitiba. Filha de José e Catarina Scharffenberg. (PASSADOS IMPERFEITOS, 2018).

Reinaldo Antonio Scharffenberg de Quadros ${ }^{11}$ é primo de segundo grau de Jânio Quadros, filho de Antonio e Maria Elisa mencionados acima. Capitão da Cavalaria do Exército e poeta ${ }^{12}$ simbolista $^{13}$ do Paraná da República Velha. Irmão de Leontina e de

\footnotetext{
${ }^{11}$ Nos anos 1950 e 1960 existia em São José dos Pinhais o Centro Cultural Reinaldo Scharffenberg de Quadros. Era uma das entidades que mais se destacava "(...) por suas promoções sociais e culturais." (CENTRO, 1961). Em 1939 o município realizou homenagem ao poeta the dando o nome de uma das ruas. A solenidade ocorreu em 1940. (O POETA, 1939). A biblioteca municipal de São José dos Pinhais também tem o seu nome, inaugurada em 1959. Curitiba também possui rua com este nome.

12 Suas poesias eram publicadas nos seguintes periódicos: Diário da Tarde, O Olho da Rua, Comércio do Paraná, Album do Paraná, Sonetos Paranaenses, Prata da Casa, Correio dos Ferroviários, Diário da Manhã, Jornal dos Poetas, todos em Curitiba. Publicou os livros "Carta Aberta ao Exo. Monsenhor dr. Francisco da Gama e Castro Mac-Dowel", "Canções Nataes" e "Os Dezoito de Copacabana". (VULTOS PARANAENSES, 1957).

${ }^{13}$ No jornal $O$ Dia, encontramos a seguinte avaliação da produção intelectual de Reinaldo S. de Quadros: “(...)poeta de grande estro, mas prejudicado em sua repercussão pelo velho complexo de timidez dos talentos paranaenses. Primoroso versejador, lírico de inspiração altíssima, manejador brilhante da língua, Scharffenberg de Quadros compôs numerosos poemas, cheios de inusitada beleza e iluminados dos fulgores de um pensamento espiritualista nobre e impressionante. (O MOVIMENTO, 1945).
} 
Revista NEP, Núcleo de Estudos Paranaenses, Curitiba, v.4, n.2, dez. 2018

Maria Elisa S. Quadros, cuja filha era Ceres Quadros Silva. É autor do poema “Os 18 do Forte", autoria rigorosamente disputada pela Academia de Letras Carioca nos anos 1950 e que foi confirmada em 1957. (O POEMA, 1957; QUADROS, 1954). Reinaldo nasceu em São José dos Pinhais, a 21 de janeiro de 1878 e faleceu em 18 de maio de 1929, no Rio de Janeiro. Em 1892 foi aprovado como aluno da Escola Militar da Praia Vermelha, no Rio de Janeiro. Com apenas 16 anos lutou nas tropas contra o Almirante Custódio de Mello ao defender o forte chamado posteriormente "Pereira Barreto". (ENTRE, 1929; SCHMIDT, 2010). Para o autor da biografia de Jânio, foi uma tragédia gerada no interior do exército que fez com que Scharffenberg ficasse conhecido nacionalmente como poeta. “A sublevação dos tenentes do Forte de Copacabana, liderada por Siqueira Campos em 5 de julho de 1922, e a consequente morte de três deles, deram ao poeta inspiração para compor sua obra-prima, Os Dezoito do Forte, mesmo nome com que o episódio ficou conhecido (ainda que não se saiba ao certo quantos eram)." (SCHMIDT, 2010).

Nesse tronco genealógico, Scharffenberg Quadros, no ano de 1905 correu os proclamas do casamento de Joaquim Ignácio de Souza com Julieta Scharffenberg de Quadros (e, posteriormente, também seria Souza). (CASAMENTO CIVIL, 1905). O casal teve os seguintes filhos: uma menina que morreu cedo; Julieta Carmen (falecida em 14 de outubro de 1997), apelido Lady, casada com João Hartman; Jehová; Joel, casado com Odette; Quinzito, dentista, formado em São Paulo, em 1932; Josoam [sic]; e Joaquim Elisio de Quadros Souza. (PASSADOS IMPERFEITOS, 2018).

Em Santa Catarina, na cidade de Brusque, ocorreu o matrimônio de Ely Cavalcanti de Quadros (filha de Antonio Scharffenberg de Quadros - inspetor de telégrafos do Paraná, falecido em outubro de 1953) - e de Robertina Cavalcanti de Quadros) com Mario Gonzaga Schaefer, filho de Otto Schaefer (adiantado industrial de Brusque) e de Anna Gonzaga Schaefer. (CASAMENTOS, 1937; NOIVADOS, 1937; MISSA, 1954). Outro filho de Antonio S. Quadros era Homero Cavalcanti de Quadros, jornalista do jornal O Dia. Em 1942, em Antonina, ocorreu o enlace deste clã, quando o filho mais jovem $2^{\circ}$ Tenente Alfredo Cavalcanti de Quadros casa-se, em 19 de fevereiro, com Vitorinha de Castro Pinheiro Lima, filha de Heitor Pinheiro Lima ( que em 1935 era tesoureiro da prefeitura de Antonina, durante a gestão do dr. Mario Ericksen) e de Parisina 
Revista NEP, Núcleo de Estudos Paranaenses, Curitiba, v.4, n.2, dez. 2018

de Castro Pinheiro Lima, ambos falecidos. (CASAMENTO, 1942). A filha Axiris de Quadros nasceu em junho de 1908. (ADMINISTRAÇÃO, 1935; REGISTRO, 1908).

Dentre os irmãos de Reinaldo Scharffenberg de Quadros também aponta-se Carmem Scharffenberg de Quadros e Sócrates Scharffenberg de Quadros, nascido em 1886, funcionário estadual, faleceu de insuficiência renal, em 1931, aos 45 anos de idade. Era casado com Maria de Jesus Lupion de Quadros, irmã do ex-governador Moisés Lupion. (OS QUE NASCEM, 1931; FALECIMENTO, 1952). Sócrates e Maria de Jesus tiveram os filhos Beatriz de Quadros Ribas, professora formada em 1933, casada com João Brasílio Ribas (falecido em abril de 2010, aos 94 anos); Saul Lupion de Quadros; e Murilo Lupion de Quadros. Neste aspecto, podemos indicar a relação de parentesco, ainda que com certo distanciamento, entre a família de Jânio Quadros e Lupion. A família Lupion é um dos clãs mais importantes politicamente da história do Paraná tendo sido marcado através das duas gestões do ex governador Moisés Lupion. Atualmente encontramos o sobrenome Lupion ainda ocupando espaços de poder no Paraná, a exemplo de Abelardo Luiz Lupion Mello, ex-deputado federal, diretorpresidente da COHAPAR, secretário de Estado da Infraestrutura e Logística e seu filho Pedro Deboni Lupion Mello, deputado estadual, eleito deputado federal em 2018

O pai de Jânio Quadros, Gabriel Nogueira de Quadros, realizou estudos primário e secundário em Curitiba. Farmacêutico, médico e engenheiro agrônomo (pela Escola Agronômica da Universidade do Paraná, formando-se em 1920). Nesse tempo, também aproveitou para iniciar paralelamente o curso de Medicina (NOTAS, 1926; SCHMIDT, 2012). Iniciou o curso de Farmácia em 1918, na Universidade do Paraná, e um ano depois pediu transferência para o curso de Medicina e Cirurgia ${ }^{14}$. Ainda que tenha trancado o referido curso em 1920 para dedicar-se em sua formação em Farmácia, concluiu Medicina em 1926, pela Faculdade de Medicina da Universidade do Paraná. No início dos anos 1920 foi proprietário da Farmácia do Povo, localizada na rua Riachuelo, em Curitiba. (SCHMIDT, 2018). Nessa área, Gabriel atuou em várias atividades, tais como inspetor sanitário da Diretoria Geral da Saúde Pública, médico do Instituto Pasteur,

\footnotetext{
14 “Registro de Diploma - Pela Diretoria Geral do Departamento Nacional do Ensino no Rio de Janeiro e Diretoria do Serviço Sanitário de São Paulo, foi oficialmente reconhecido e registrado o diploma de Doutor em Medicina, expedido pela Faculdade de Medicina do Paraná ao sr. dr. Gabriel Nogueira de Quadros.” (REGISTRO, 1927).
} 
Revista NEP, Núcleo de Estudos Paranaenses, Curitiba, v.4, n.2, dez. 2018

foi chefe do serviço de profilaxia de Moléstias Venéreas, auxiliar de profilaxia Rural Federal, médico da Caixa dos Aposentadorias e Pensões da estrada de Ferro São PauloRio Grande. (MUNICÍPIO DE POLONI, 2018; SCHMIDT, 2012). Após formar-se em Medicina, foi clinicar no Mato Grosso do Sul. Também foi médico da Cerâmica Pinhais, ex interno da clínica Cirúrgica da Santa Casa de Misericórdia de Curitiba, médico da S.B. Companhia Cervejaria Atlântica S.A. além de ter consultório no Matadouro Velho, n. 30. (WITTIG, 2018).

Além do jornalismo, Gabriel de Quadros também foi professor no Paraná e Mato Grosso, lecionando Legislação Comercial no Instituto Comercial de Curitiba. Em ambos estados participou de atividades políticas. Em terras paranaenses, “(...)no período da revolução de trinta, trabalhou politicamente contra o partido da Aliança Liberal [Gabriel era vinculado ao o então presidente do Paraná, Affonso Alves de Camargo ${ }^{15}$ ], recebendo como represália a perda de seus empregos públicos no Paraná, o que tornou sua situação financeira difícil, obrigando transferir-se para a cidade de São Paulo em 1930”. (WITTIG, 2018). Durante a época da respectiva Revolução de 1930, como soldado, lutou ao lado das tropas de São Paulo e, em 1932, foi tenente-médico do MMDC. (MUNICÍPIO DE POLONI, 2018).

A aproximação de Gabriel com Affonso Camargo ocorreu nos tempos em que dirigia o semanário Paraná-Jornal, criado por ele (diretor-proprietário e redator-chefe), em 1918, para divulgar em primeiro plano as atividades da União dos Acadêmicos de Agronomia. Com o tempo o jornal passou a apresentar artigos variados, inclusive com destaques para a situação política do Paraná numa perspectiva elogiosa, época em que Affonso Camargo estava em seu primeiro mandato como governador.

\footnotetext{
15 Affonso Camargo, membro de família histórica e tradicional do Paraná vinculada à grande propriedade, na região dos Campos Gerais. Nasceu em Guarapuava, a 25 de setembro de 1873 e faleceu e Curitiba, em 16 de abril de 1959. Filho de Pedro Alves da Rocha Loures e de Francisca de Camargo Loures. Advogado, formado em Direito pela Universidade do Paraná, obteve os seguintes cargos políticos: deputado estadual (1897-1898, 1899, 1900-1901, 1906, 1914-1915), deputado federal (1921-1922), senador (1922-1927) e governador (1916-1920 e1928-1930). Affonso Camargo iniciou carreira política na agremiação oposicionista chamada primeiramente de União republicana e, depois de 1897, de Partido Republicano. Após a união partidária de 1908, participou do Partido Republicano Paranaense. (GOULART, 2014). Atualmente, a família Camargo conta com nomes importantes no Judiciário como Cleiton Camargo e sua filha Vanessa Camargo. Seu filho Fábio Camargo, ex-deputado estadual, foi para o Tribunal de Contas. (OLIVEIRA, 2012).
} 
Revista NEP, Núcleo de Estudos Paranaenses, Curitiba, v.4, n.2, dez. 2018

Após a conclusão do curso de Medicina, em 1927 Gabriel e sua família (esposa e filhos) mudaram-se para o estado de São Paulo, primeiro para o município de Garça e depois para Bauru (cidades do centro paulista). Porém, um ano depois retornaram para Curitiba, local onde ficariam até 1930, quando eclode a chamada Revolução de 30 e Gabriel, por ser funcionário público do estado e ligado à figura de Afonso Camargo, que estaria em seu segundo mandato no governo do estado, obriga-se novamente a mudar-se da capital paranaense. Nesse último período em que Gabriel e seus familiares moraram em Curitiba, envolve-se no Partido Republicano Paranaense, chefiado pelo então governador Affonso Camargo, além assumir a chefia da área de doenças venéreas da Diretoria de saúde Pública. Período em que se encontra pela primeira vez com estabilidade financeira, além de significativas relações sociais e políticas, pois vislumbrava sua candidatura à Câmara Federal como deputado pelo Paraná. (SCHMIDT, 2012).

Quando as tropas revolucionárias de Vargas chegaram em Curitiba, em 5 de outubro, Affonso Camargo deixara o governo e fugia com sua família para São Paulo. Gabriel, funcionário público com cargo importante em secretaria de governo, foi preso em sua residência por declarar apoio ao então presidente Washington Luís e Júlio Prestes, sendo preso por conta deste posicionamento. A soltura ocorreu somente dias depois da posse de Vargas, em 3 de novembro. Em dezembro de 1930, novamente a família de Jânio voltaria para o estado paulista, fixando residência primeiramente no interior e depois para São Paulo capital. (SCHMIDT, 2012).

Em 1951, Gabriel ${ }^{16}$ foi eleito vereador em São Paulo (1952-1955), pelo Partido Democrata Cristão (PDC). Nas eleições de 1954, enquanto suplente assumiu a cadeira de deputado estadual $^{17}$ (1955-1960) pelo Partido Trabalhista Nacional (PTN). Gabriel faleceu em 18 de maio de 1957. Gabriel Quadros foi assassinado em São Paulo, no dia 18 de maio de 1957, em polêmica briga com o feirante José Guerreiro, em caso passional

\footnotetext{
${ }^{16}$ Embora não seja objetivo desenvolver a biografia de Gabriel, vale ressaltar que sua fama como médico e o desenrolar de sua vida financeira foi marcada por práticas abortivas. Fato que esteve constante em vários jornais e também na relação difícil entre Jânio e seu pai, conforme aponta Schmidt (2012).

17 “Dr. Gabriel de Quadros era um homem temperamental, difícil e autoritário, colocando-se em conflitos pessoais. (...) Faleceu assassinado no exercício de mandato em 18/05/1957).” (WITTIG, 2018).
} 
Revista NEP, Núcleo de Estudos Paranaenses, Curitiba, v.4, n.2, dez. 2018

com a mulher deste, Francisca Flores, vulga Nena, na disputa de gêmeos com paternidade duvidosa ${ }^{18}$.

No velório de João Manoel de Quadros ${ }^{19}$, avô de Jânio, constam nomes de vários familiares: Serafina de Quadros Luz, Antonio Manoel de Quadros, Manoel Joaquim de Quadros, Maria das Dores e Miranda (casada com Manoel José de Miranda), Luiz Gonzaga de Quadros (filho), Sebastião Augusto de Quadros, Dr. Miguel de Quadros (filho), Gabriel Nogueira de Quadros (filho), Julia de Souza Quadros. (MISSA, 1913). João, coronel da Guarda Nacional e chefe político de Rio Claro, teve três matrimônios. (JOÃO QUADROS, 2018). Foi casado primeiramente com Ana Avelina Nogueira, filha do Coronel Marcelino José Nogueira, chefe político em São José dos Pinhais ${ }^{20}$ e Maria Joaquina da Conceição Nogueira, em segundas núpcias com Maria Pires Baptista e o terceiro casamento foi com Guilhermina Quadros. Do primeiro casamento, com Anna Avelina, teve nove filhos, sendo que dois não sobreviveram. Os sete filhos são: Maria Julia de Quadros ${ }^{21}$, Manoel Joaquim de Quadros, Maria das Dores Quadros, Luiz Gonzaga de Quadros, Sebastião Augusto de Quadros, Miguel Nogueira de Quadros e Gabriel Nogueira de Quadros (pai de Jânio). Anna faleceu dia 15 de fevereiro, aos 39 anos de idade. (SCHMIDT, 2012).

João não teve filhos do segundo casamento com Maria Pires Batista, haja vista que sua esposa faleceu subitamente após três meses do enlace, ocorrido em 1896. Do terceiro casamento com Guilhermina Gonçalves, realizado em 12 de junho de 1897, tiveram os seguintes descendentes: Maria (que faleceu dias depois de seu nascimento), Maria Dorothea (Tetéia), João (faleceu com apenas quatro meses), João (Janguito), Herculano, Marília (Lili, falecida em 1952), Álvaro (Vico), Lauro (falecido aos 11 meses) e os gêmeos Marcílio e Marcília (ela faleceu antes de completar dois meses). (SCHMIDT, 2012). Guilhermina faleceu em 27 outubro de 1909, segundo notícia do jornal $A$

\footnotetext{
18 Disponível em: <https://glamurama.uol.com.br/direto-da-revista-j-p-o-assassinato-do-pai-de-janioquadros/ >. Acesso em: 28/10/2018.

${ }^{19}$ Como último desejo, João foi enterrado no Cemitério Municipal de Curitiba, num jazigo acima ao de sua mãe, Maria Claro. (SCHMIDT, 2012).

20 Genealogia Paranaense. Francisco Negrão.Volume II-351 e III-555 e IV-474.

${ }^{21}$ Segundo Schmidt (2012), há possibilidade de Maria Julia ter sido adotada pelo fato de que não foi encontrado registro de seu nascimento, diferente dos demais irmãos.
} 
Revista NEP, Núcleo de Estudos Paranaenses, Curitiba, v.4, n.2, dez. 2018

República. (PASSAMENTO, 1909; FALECIMENTOS, 1946; FALECIMENTOS MANOEL, 1926; EDITAL DE CITAÇÃO, 1963).

O jornal Província do Paraná de 1879 aponta que João era proprietário de uma casa de negócios em Borda do Campo, a qual estava em dívida com o governo da Província por não pagamento de impostos. (TESOURO, 1879). Também em 1881 era habilitado eleitor na freguesia de Campina Grande, no $1^{\circ}$ distrito, $21^{\circ}$ quarteirão. (ALISTAMENTO, 1881). Em 1888 João Manoel de Quadros foi candidato a deputado provincial pelo Partido Conservador (PC), na mesma chapa de Antonio Pospissil, Visconde de Nácar e Barão do Serro Azul, entre outros. (CANDIDATURA, 1888). Porém, não foi eleito. (ALVES, 2015). O jornal A República, de 1899, indica que João Manoel foi juiz distrital em Rio Claro. (PERSEGUIÇÃO, 1899).

Consta que era morador de Rio Claro no ano de 1902, além de negociante em Curitiba. No mesmo ano, João se destacou como presidente do diretório local do Partido Republicano Federal ${ }^{22}$ (PRF), situacionista, em Rio Claro, juntamente com Luiz de Oliveira Quadros (secretário), Florentino José Marques, João Rodrigues de Lima e Emílio de Paula Cordeiro. Foi reeleito para o mesmo diretório em 1905. (RIO CLARO, 1902). Em 1903, nomeado por decreto de 6 agosto de 1903, subcomissário de polícia no distrito de Rio Claro, termo de São João do Triumpho (eleitor neste local, em 1890). (FATOS, 1903). No ano de 1908, João Manoel dissolveu a sociedade comercial que tivera com seus filhos desde 1901, apresentando no jornal Diário da Tarde os seguintes termos:

Comunicamos ao comércio e ao público em geral, que em 31 de dezembro de 1908 e na melhor harmonia, dissolvemos a sociedade comercial que girou sob a firma [sic] de 'Quadros \& Filhos', com casa matriz em Rio Claro e filial em S. Pedro, saindo os sócios pagos e satisfeitos de seus capitais e lucros e nada ficando a firma a dever à praça, ou a quem quer que seja. Aproveitamos para agradecer ao comércio e à freguesia, a confiança e amizade, com que tanto honraram a nossa firma. Rio Claro, $1^{\circ}$ janeiro de 1909 . Manoel Joaquim de Quadros [filho], Luiz Gonzaga de Quadros [filho] e João Manoel de Quadros. (AO COMÉRCIO, 1909).

22 O Partido Republicano Federal era a agremiação situacionista, controlava a maior parte das cadeiras na Assembleia Legislativa do Paraná, assim como a maioria das prefeituras do estado. O partido tinha como liderança Vicente Machado da Silva Lima. Em 1908, em meio à Coligação Partidária realizada com a agremiação oposicionista, o Partido Republicano, sob as ordens de Generoso Marques dos Santos, fundouse o Partido Republicano Paranaense. O PRPr controlaria a política estadual até 1930. (GOULART, 2014). 
Revista NEP, Núcleo de Estudos Paranaenses, Curitiba, v.4, n.2, dez. 2018

João Manoel de Quadros faleceu ${ }^{23}$ no dia 3 de novembro de 1913, vítima de lesão na aorta. (ataque cardíaco). (AGRADECIMENTOS, 1913; OS QUE MORREM, 1913).

No que tange às conexões de poder e vínculos com famílias e grupos importantes do Paraná, pode-se dizer que os tios paternos (e também maternos, conforme veremos adiante) de Jânio foram fundamentais para o desenvolvimento de laços políticos, bem como foram inspiração e influência no direcionamento de seus estudos, como o tio Miguel. Contudo, estes também revelaram traços de autoritarismo e violência, certamente alguns absorvidos por Jânio, conforme revela Schmidt (2012), bem como os vários relatos encontrados em jornais da época. Porém, há que se dizer, nada tão diferente do padrão histórico da classe dominante e dos bacharéis em Direito do Brasil e do estado do Paraná. (SOUZA, 2015; SOUZA, 2017; OLIVEIRA et al. 2017; OLIVEIRA, 2001; 2012; 2018).

Sobre os tios de tias do lado paterno, ressaltaremos os principais aspectos de suas trajetórias individuais e familiares, bem como as importantes conexões sociais estabelecidas com outros grupos familiares, os quais tornam a família de Jânio Quadros ainda muito importante no estado do Paraná, tendo em vista que muitos nomes correlacionados se encontram no poder, tanto no estado quanto na cidade de Curitiba.

Ainda que não se tenha certeza de sua ligação biológica, Maria Júlia de Quadros é identificada como a primeira filha de João Manoel de Quadros. (SCHMIDT, 2012). Nascida em 22 de março. Casou-se com Manoel Gonçalves em 1912. (CONTRATOS, 1912). Estudou na Escola Normal, mesmo após seu casamento.

Manoel Joaquim de Quadros, Maneco, nascido em 5 de outubro de 1878. Casou-se com a prima Leontina, filha do tio Antonio Manoel de Quadros. (SCHMIDT, 2012). Membro do conselho diretor da Cruz Vermelha. Foi também $2^{\text {o }}$ secretário da Sociedade de Socorro aos Necessitados, inclusive membro da primeira diretoria, criada em 1921. (ANIVERSÁRIO, 1981). Faleceu de câncer no estômago, em 14 de dezembro de 1926, aos 46 anos. Era comerciante em Curitiba. (SCHMIDT, 2012).

\footnotetext{
${ }^{23}$ Vale ressaltar que os médicos que acompanharam o tratamento de saúde de João ao longo de muito tempo foram João Cândido Ferreira, ex governador do Paraná, vice-governador na época da gestão de Vicente Machado, e Victor Ferreira do Amaral (SCHMIDT, 2012), deputado estadual, secretário de governo e primeiro Reitor da Universidade do Paraná. Ambos membros nomes importantes da política estadual, além de representantes de famílias tradicionais do estado. (OLIVEIRA, 2001; GOULART, 2014).
} 
Revista NEP, Núcleo de Estudos Paranaenses, Curitiba, v.4, n.2, dez. 2018

Maria das Dores Quadros (Maricas), nasceu em 27 de abril de 1881. Casouse em Rio Claro, no ano de 1895, com Manoel José de Miranda, comerciante de Curitiba e de Rio Claro. Proprietário de fábrica de manteiga de nata, em 1905. (EDITAL DE CITAÇÃO, 1963). Foi diretor do instituto de comércio de Paranaguá em 1913. Tiveram as filhas Iracy; Danila; Samiramis; Donatilla; Almira Quadros de Miranda, casada com o dr. Dagoberto Silva, funcionários dos correios e telégrafos, em 2 de outubro de 1937; Celina, casada com o engenheiro civil Pedro Paulo Flenick. (ENLACE MIRANDASILVA, 1937).

Luiz Gonzaga de Quadros é outro tio de Jânio que merece destaque. Nasceu em 21 de junho de 1882, na Villa de Deodoro. Em 1901, seu pai, João Manoel de Quadros, decretou que Luiz Gonzaga e Manoel Joaquim de Quadros se tornaram sócios junto com ele da empresa Quadros \& Filhos. O comércio seria de compra e vendas de fazendas, ferragens e molhados no distrito de Rio Claro; cuja empresa fora encerrada na Junta Comercial em 1904. (OS BACHAREL[sic], 1917; SECÇÃO, 1901). Em 1909 seu nome aparece na lista de comerciantes e industriais do Paraná coadunados com a homenagem realizada ao então presidente da Associação Comercial do Paraná (ACP), Pamphilo d'Assumpção. (DR. PAMPHILO, 1909).

Advogado, iniciou seus estudos na Faculdade de Direito do Paraná, na primeira turma de 1913, formando-se em 1917. Nessa época, foi contemporâneo de jovens pertencentes às famílias influentes do Paraná, tais como Hugo Simas, Theóphilo Gomy Junior, Generoso Borges, João Soares Barcellos, Tasso da Silveira, J.C. de Andrade Muricy, Juvenal Camargo (que trancou a matrícula no final de 1913), Leônidas de Loyola, Oscar Borges de Macedo e Oscar Martins Gomes, entre outros. (A UNIVERSIDADE, 1972). Em 1915, antes de forma-se bacharel, já assumia atividades na área advocatícia, tendo impetrado ao Superior Tribunal "habeas-corpus" para seu cliente. (NOTICIÁRIO, 1915). Recém-formado, Luiz Gonzaga de Quadros possuía escritório de advocacia em Curitiba, em 1918, na avenida Marechal Floriano, n.2, tendo como sócios Marcelino Nogueira Junior, João Carlos H. Gutierrez e M. de Lacerda Pinto. (DRS. MARCELLINO, 1918). Em 1943, seu endereço profissional ficava na praça Tiradentes. Dentre seus clientes constam as empresas Emílio Romani \& Cia e Feliciano Guimarães \& Cia. Luiz Gonzaga era Conselheiro da OAB Paraná no ano de 1943. (ADVOGADOS, 1929). 
Revista NEP, Núcleo de Estudos Paranaenses, Curitiba, v.4, n.2, dez. 2018

No que diz respeito aos vínculos políticos, em 1905, Luiz Gonzaga de Quadros participava do diretório do Partido Republicano Federal em Rio Claro, junto com os seguintes representantes: João Manoel de Quadros (seu pai), Alberto Fandosky, Julio Budant e João Martins. (TRIUNPHO, 1905). Em 1934, participou da fundação do Partido Social Nacionalista (PSN), que ocorreu em Jaguariaíva, além de proferir discurso assinalando a necessidade de os paranaenses engrossarem as fileiras da referida agremiação. (PÁGINA, 1934). Nesse contexto, atuou como membro do diretório central do PSN junto com fortes representantes da política paranaense da República Velha, entre eles: cel. Joaquim Pereira de Macedo, Gal. Mario Tourinho, Cap. Catão Menna Barreto Monclaro, cel. Roberto Glasser, Francisco A. Guérios, Alceu do Amaral Ferreira, Emílio Neiva, Francisco Franco, Marcellino Nogueira Junior, Benjamin Lins de Albuquerque e Oscar Martins Gomes. (PARTIDO, 1934).

Em 3 de setembro de 1907 a família Quadros protagonizou um dos episódios que marcou o início da República em Rio Claro. João Manoel de Quadros (pai de Luiz Gonzaga) na condição de subcomissário de polícia, prendeu o colono Miguel Gruchkowsky sob a acusação de um roubo feito em São Mateus. Porém, no dia seguinte, o então jovem Luiz Gonzaga de Quadros, junto com Benedicto Baptista, entrou na cadeia e ambos fecharam as portas para dar uma "forte surra", ou melhor, espancar veementemente, com o uso de chicote, o referido acusado. Contudo, ainda que mediante sindicância e comprovação do fato ${ }^{24}$, nada foi feito a respeito, nem ao pai que seria o responsável pela delegacia e tão menos ao filho que fora o autor da violência. (COLONO, 1907).

Luiz Gonzaga foi casado com Helena Buezek de Quadros. Não tiveram filhos. Faleceu em Curitiba, aos 64 anos de idade, no dia 13 de julho de 1946. (FALECIMENTOS, 1946).

Sebastião Augusto de Quadros, industrial, major, é outro tio paterno de Jânio que também teve envolvimento direto na política do Paraná. Em 1925 fez parte do

\footnotetext{
24 “Da sindicância feita pelo sr. capitão Aleluia Santos, no núcleo colonial Rio Claro, está verificado que o espancamento do colono Miguel Gruchkowski, foi praticado por Luiz Gonzaga de Quadros e Benedicto Baptista, o primeiro filho do subdelegado daquela localidade João Manoel de Quadros." (ESPANCAMENTO, 1907).
} 
Revista NEP, Núcleo de Estudos Paranaenses, Curitiba, v.4, n.2, dez. 2018

diretório local do $\operatorname{PRPr}^{25}$ (Partido Republicano Paranaense) em União da Vitória ${ }^{26}$, na época em que o senador Affonso Camargo era presidente da referida agremiação. (PELA POLÍTICA, 1925). Sebastião era proprietário de terras na região do Palmital, próximas à estação Paulo Frontin. (PROTESTO, 1910).

Participou da Guarda Nacional, sendo tenente secretário, em 1907, transferido para o $38^{\circ}$ regimento da cavalaria, em Palmeira. (GUARDA, 1907).

Também pode-se detectar a violência, o conflito resolvido pelo uso da força como padrão comportamental familiar ${ }^{27}$, o habitus ${ }^{28}$ de classe, como conceitua Pierre Bourdieu. Em 1923 ocorreu significativo contenda entre Sebastião e colonos descendentes de poloneses, assim como seu irmão, Luiz Gonzaga de Quadros, conforme mencionado anteriormente. Segundo jornal Comércio do Paraná, de 1923, há tempos Sebastião tinha negociado terras, na região de Carasinho $^{29}$, com colonos e vendido diversos lotes sem ter declarado escritura. Contudo, resolver construir estrada nesses mesmos terrenos para poder construir uma entrada mais adequada em suas terras. Porém, mesmo sem autorização dos donos, adentrou com os trabalhadores e roçadeiras nos respectivos terrenos com a ajuda do primeiro suplente que estava exercendo provisoriamente a subdelegacia e que também era agrimensor, José João Pawlowski, que agiu, neste caso, com interesse particular de profissional. Ao invadir, obteve reação por parte dos moradores que respeitavam e lei e exigiam o mesmo respeito, conforme destacou o jornal. A invasão resultou em tiroteio e um dos tiros disparados pelo

\footnotetext{
${ }^{25}$ O PRPr, Partido Republicano Paranaense, é o resultado da união entre o Partido Republicano Federal (situacionista) e o Partido Republicano, que até 1908 representava a oposição política no estado. Com a morte de Vicente Machado em 1907, que controlava o grupo da situação, as principais lideranças articularem que seria mais interessante consolidar ambas as forças em um único partido. O PRPr controlou os principais cargos e absorveu as maiores lideranças políticas até 1930. (GOULART, 2014).

${ }^{26}$ Demais membros do diretório local: Francisco Cleve, Leopoldo de Castilho, Dr. Rivadávia Marcondes, Innocêncio de Oliveira, Francisco Machado e João Pedro Riesemberg.

${ }^{27}$ Como exemplo significativo desta questão, embora não tenhamos conhecimento do conteúdo e razões do conflito entre os irmãos, o jornal A República, de 1922, traz a seguinte nota: "XXX - Atendendo o pedido que lhe fora feito o sr. dr. Chefe de Polícia oficiou ao delegado de Polícia de Porto União, mandando garantir o sr. João Gonçalves Quadros contra o sr. Sebastião Augusto de Quadros.” (NOTAS, 1922). A briga entre os irmãos também foi mencionada por SCHMIDT (2012).

${ }^{28}$ Podemos entender o habitus, via Bourdieu, como "(...)o modo como a sociedade se torna depositada nas pessoas sob a forma de disposições duráveis, ou capacidades treinadas e propensões estruturadas para pensar, sentir, e agir de modos determinados, que então as guiam nas suas respostas criatividades aos constrangimentos e solicitações do seu meio social existente. (CATANI et al., 2017).

${ }^{29}$ Nome da fazenda situada na região de Rio Claro.
} 
Revista NEP, Núcleo de Estudos Paranaenses, Curitiba, v.4, n.2, dez. 2018

subdelegado atingiu de raspão a senhora Pelagia Janoriwsky. Questão comprovada pelo próprio inquérito realizado pelo então Chefe de Política, Heitor de Alencar Guimarães ${ }^{30}$. (RESPONDENDO, 1923). Para fechar o artigo com as informações mencionadas acima, Francisco Brzezinski, o subdelegado que estava em viagem quando ocorreu o conflito, apontou o seguinte aspecto:

\begin{abstract}
Vou concluir dando um conselho ao sr. Quadros, que continue sempre a ser, "chefe político local situacionista", pachá e sultão se assim lhe convier, e pescador das águas turvas se assim lhe apraz, mas que me deixe em paz e vá amolar o boi se ele ainda não morreu. - Demais, o sr. Quadros creio que conhece aquele adágio "Quem tem rabo de palha não se senta perto do fogo", se achar que é pouco o que acima disse, guardado tenho aqui coisinhas que só mesmo obrigado trarei a luz do dia para conhecimento do público. É o que tenho a dizer. Francisco Brzezinski. (RESPONDENDO, 1923).
\end{abstract}

Sebastião Augusto de Quadros faleceu em maio de 1956. A Assembleia Legislativa do Paraná, através da menção proferida pelo orador deputado Anibal Khury, inseriu em ata voto de pesar levando ao conhecimento dos parentes enlutados, destacando a importância do referido clã ao Paraná: “(...)membro de tradicional família paranaense residente em União da Vitória”. Grifo nosso. (VOTO, 1956). Sebastião foi casado com Antonieta M. de Quadros.

Miguel de Quadros, tio de Jânio, advogado e jornalista. Nasceu em 25 de maio de 1886. Casou-se, em outubro de 1911, com Clorys Vianna de Quadros, falecida em 31 de agosto de 1921. (VISA, 1922). Clorys era filha de Pedro Viana Guimarães, sócio do importante estabelecimento comercial Viana Chaves \& Cia, do Rio de Janeiro. (ÚLTIMAS, 1915). Miguel formou-se em Direito, pela Faculdade do Rio de Janeiro, em 1912. Era presidente da subseção da Ordem dos Advogados do Paraná, com sede em Ponta Grossa. (EDITAL DE CITAÇÃO, 1963).

Filhos com Clorys: Jacyr, médico (nascido em 1915), Eunice Quadros Cunha (casada com Darcy Cunha), Cylene Vianna de Quadros (casada em 1937 com Frederico Waldemar Lange Filho, filho do comerciante Frederico Lange e de Paula Lange) e Elyrio (nascido um mês antes de sua mãe falecer). (ENLACE, 1937; DR. MIGUEL, 1937).

\footnotetext{
${ }^{30}$ Irmão do ex-senador Manoel de Alencar Guimarães, anteriormente citado.
} 
Revista NEP, Núcleo de Estudos Paranaenses, Curitiba, v.4, n.2, dez. 2018

Do segundo casamento, com Rumília teve Clarice Almeida Quadros (casada em 1942 com Dirceu Rodrigues Dalledone, filho de Joaquim Antonio Dalledone e de Maria Augusta Rodrigues Dalledone), Lycius e Glaucus. (RODRIGUES, 1942).

Miguel tinha escritório de advocacia em Ponta Grossa, em sociedade com o dr. Oliveira Franco. (COMUNICAÇÕES, 1911).

Ainda estudante, Miguel de Quadros entra em conflito com o então senador e deputado estadual de renome da República Velha, Manoel de Alencar Guimarães ${ }^{31}$. No Rio de Janeiro, Miguel publica um artigo denunciando o referido senador e o acusa de têlo mandado matar. A imprensa paranaense, por meio do jornal Diário da Tarde, reproduz os principais pontos de sua denúncia:

Rio, 8. O estudante paranaense Miguel Quadros publica um artigo, baseado em informações que recebeu daí e no qual responsabiliza o sr. Manoel Guimarães pelo provável atentado a sua vida por capangas desse senador. Diz que fará uma campanha extrema contra os nortistas que desmoralizaram o Paraná, sugando o Estado. O sr. Miguel Quadros termina dizendo que desafia o senador argentino a que o mande assassinar. (ATAQUE, 1910).

Nove anos depois, 1919, Miguel estabelece outra hostilidade com político importante do Paraná, entra em conflito com Marins Camargo ${ }^{32}$, onde, por parte deste, consta as seguintes afirmações e acusações sobre Quadros:

\begin{abstract}
"Eu tive realmente a imprudência de lhe perturbar a digestão das terras de Floresta e das Campina Bellas, que esse Gargantua pretendia engolir de um só fôlego, lesando os legítimos proprietários daquelas terras, entre eles, viúvas e órfãos. Tenho agido no interesse dos meus constituintes, escandalosamente roubados, e fiz mais ainda: tenho contribuído eficazmente ao sentido de evitar que esse advogado ladravaz, valendo-se de desprezíveis chicanas, lese o Estado em centenas de contos de réis. Se é esse o meu crime, eu sou um criminoso. Quanto às imputações que me fez o sr. Quadros em sua verrina,
\end{abstract}

\footnotetext{
${ }^{31}$ Manoel de Alencar Guimarães, advogado, juiz, secretário de governo e político importante da República Velha. Membro de família da classe dominante tradicional do Paraná, pelo lado paterno era neto do Visconde de Nacar, ervateiro poderoso do Império. Do lado de sua mãe era neto de José de Alencar, conselheiro e romancista brasileiro. Possui fortes conexões políticas e econômicas, além de genealogias de poder que chegam aos dias atuais. Foi deputado estadual por 12 vezes 91892, 1893-1894, 1895-1896, 18971898, 1899, 1902-1903, 1906-1907, 1908-1909, 1910-1911, 1912-1913, 1914-1915, 1935-1937), deputado federal (1895-1896, 1897-1899, 1900-1902, 1903-1905, 1906-19080, senador (1908-1911, 1912-1920) e governador interino em 1908 enquanto presidente da ALEP (Assembleia Legislativa do Paraná). (GOULART, 2014).

${ }^{32}$ Irmão do então governador Affonso Alves de Camargo. Foi deputado estadual em 1910-1911, 19181919, 1920-1921, senador 1928-1930, secretário de governo em três pastas, além de promotor público e professor na Universidade do Paraná. (GOULART, 2014).
} 
Revista NEP, Núcleo de Estudos Paranaenses, Curitiba, v.4, n.2, dez. 2018

desprezo-as por partir de um advogado completamente destituído de senso moral, e que não tem pejo de roubar até viúvas de operários, como provarei se necessário for. Marins Camargo.” (OS DETRATORES, 1919).

Contudo, apesar de várias desavenças com nomes importantes da política partidária estadual, em 1929, Miguel de Quadros é uma das lideranças políticas de Ponta Grossa, representante do Partido Republicano Paranaense do respectivo município perante o então governador do Paraná, Afonso Camargo, irmão de Marins.

No ano de 1923, Miguel de Quadros fora reabilitado jurídica e moralmente no campo jurídico como advogado em Ponta Grossa devido pena disciplinar recebida porque reteve de forma indébita dos autos de uma falência em que era advogado de uma das partes. Contudo, sobre sua reabilitação, segue telegrama revelando apoio das figuras importantes da política do Paraná: "Ponta Grossa, 12 [junho de 1923]. O ato do Tribunal anulando a pena de suspensão do dr. Miguel de Quadros causou grande e geral satisfação nesta cidade, principalmente aos numerosos amigos daquele ilustre advogado a quem felicitamos. (a.). Brazílio Ribas; dr. Francisco Burzio; Rodolpho Ribas; Euzébio Rosas; Ernesto [Guimarães] Villela; José Pedro Carvalho; Theóphio Cunha; Fernando Bittencourt; farmacêutico Milach; Eugênio Gam Basi; Victor Baptista; Bonifácio Ribas.” (O CANCELAMENTO, 1923).

Em sociedade com Francisco Búrzio ${ }^{33}$, (cel.) José Pedro da Silva Carvalho ${ }^{34}$ e Ernesto Guimarães Vilella ${ }^{35}$ (citados anteriormente), Miguel de Quadros organiza e funda a Empresa Paranaense de Mineração e Colonização no ano de 1924. O empreendimento tinha o objetivo de explorar ouro, diamante e carbonatos no rio Tibagi. (SCHMIDT, 2012).

Em 1926, Miguel de Quadros presidiu a empresa que construiu a vila operária em Ponta Grossa. Formada por diversas casas de madeira, as residências tinham o

\footnotetext{
${ }^{33}$ Médico, residente em Ponta Grossa, em 1925. (A EQUITATIVA, 1925). Inclusive, Francisco era médico particular de Miguel de Quadros quando este se encontrava enfermo ano de 1925. Casado com Izabel Búrzio. (ENFERMO, 1925).

${ }^{34}$ Comerciante (exportador de madeira e fazendeiro em Ponta Grossa. Foi vereador em Ponta Grossa nos anos 1883-1886.

35 Chefe político de Ponta Grossa e membro do Partido Republicano Paranaense em 1924. (MEMORANDUM, 1899). Foi prefeito de Ponta Grossa no período de 1896-1908 e vereador nas legislaturas de 1887-1889 e 1890-1891. (UNIÃO, 1947).
} 
Revista NEP, Núcleo de Estudos Paranaenses, Curitiba, v.4, n.2, dez. 2018

objetivo de favorecer os operários tendo em vista que eram cobrados aluguéis módicos de seus moradores. (UMA VILA, 1926).

Consta que em 1936, Miguel era sócio em escritório de advocacia dos srs. Luiz Gonzaga de Quadros, João Carlos Gutierrez e Marcellino Nogueira Sobrinho, os quais tinham escritório em Curitiba, e Miguel atendia em Ponta Grossa. (ESCRITÓRIO, 1936).

Porém, ainda que em meio a uma trajetória de importante reconhecimento advocatício, Miguel irá travar briga com o então interventor de Getúlio Vargas no Paraná, Manoel Ribas, este seria o mais severo de seus conflitos. Após assumir a administração do estado, em 1932, Manoel Ribas, que era natural de Ponta Grossa, passou a realizar uma espécie de sindicância nas contas da referida prefeitura com o objetivo de atingir politicamente o prefeito Cel. Victor Antonio Baptista ${ }^{36}$, amigo de Miguel de Quadros, no qual se posiciona em sua defesa. Travam, então, batalha na imprensa local e estadual. (SCHMIDT, 2012). Desta situação de embate, Miguel é preso e encarcerado por oito dias no quartel do Corpo de Bombeiros de Curitiba, sem saber ao certo qual seria a acusação que lhe era feita. O fim da prisão se deu pelo trabalho de seu irmão Luiz Gonzaga de Quadros. O advogado prometeu a si mesmo que iria vingar-se. Nas palavras de Schmidt (2012, p.80): "Miguel tinha em sua personalidade um traço de agressividade [como dos demais irmãos] tão intenso quanto o de Ribas, e ao sair do quartel fez sua promessa chegar ao interventor."

Contudo, três anos depois, no dia 14 de outubro de 1935, ao levar seu filho Glaucus ao oftalmologista, Miguel de Quadros percebeu que Manuel Ribas estava na cidade e o localizou no Café Éden Teatro, para falar-lhe o que tinha prometido a si mesmo. Manoel Ribas estava na companhia do então prefeito Albary Guimarães, Adherbal Stresser (redator da Gazeta do Povo), João Nociti (comerciante de Curitiba), cel. José Vilella (industrial e membro do PSD) e João Ricardo Borell du Vernay (alto funcionário federal). A imprensa detalha o seguinte: “O dr. Miguel despejou uma série de doestos [sic] contra o operoso chefe do executivo paranaense, dos quais a ética profissional e o respeito que devemos a alta autoridade que é o sr. Manoel Ribas nos impedem de

\footnotetext{
${ }^{36}$ Foi nomeado pelo governador Caetano Munhoz da Rocha e empossado para o cargo em 9 setembro de 19124. Membro do Partido Republicano Paranaense e presidente do diretório local de Ponta Grossa.
} 
Revista NEP, Núcleo de Estudos Paranaenses, Curitiba, v.4, n.2, dez. 2018

reproduzir aqui." (O LAMENTÁVEL, 1935). Contudo, Schmidt (2012, p. 119) destaca que Miguel proferiu as seguintes palavras:

\begin{abstract}
_ Cachorro! Ordinário! Cafajeste! Sem-vergonha! _o sorriso desapareceu imediatamente dos lábios de Ribas [que se moveu para "cumprimentar" ironicamente Miguel de Quadros]. Miguel continuou _ Eu lhe avisei que na primeira oportunidade que tivesse, diria na sua cara o que penso de sua pessoa! Ribas levou a mão a um dos bolsos, à procura de sua arma. Miguel, já com a mão em seu revólver, arrematou:

_ Puxe essa arma se você for homem, seu canalha, e você morre aí mesmo sentado, como o verme que você é!

$\mathrm{O}$ interventor afastou as mãos e logo veio o dono do clube [José Pierre] e procurou apaziguar Miguel, pedindo-lhe que não tomasse atitude impensada. Já na porta, gritou a Ribas:

_Vamos resolver isto no campo da honra! Escolha as armas e o local para nos batermos!
\end{abstract}

O fato é que Miguel tinha desafiado diretamente Manoel Ribas. Procurado pela imprensa local, Miguel respondeu que suas palavras foram frutos do que havia passado por sua prisão injusta em 1932, pois seu confinamento teria prejudicado sua prestigiosa carreira de advogado. Para Miguel, o insulto público ao interventor teria sido sua desforra. (O LAMENTÁVEL, 1935). Entretanto, no dia 10 de novembro de 1937, pouco mais que dois anos depois do conflito com Manoel Ribas, Miguel de Quadros sobre um atentado em sua própria chácara (no bairro Uvaranas), pela manhã, quando tratava das galinhas que criava em seu quintal. Ficou dois dias hospitalizado e veio a falecer no dia 12 de novembro. Diante dos fatos anteriores, abre-se uma enorme comoção sobre o assassinato de Miguel de Quadros e quem o teria feito. A imprensa discutiu a prisão de supostos bandidos e também acompanhou a soltura do inocente Barbosa Paraná.

Acusado de ter assassinado o dr. Miguel de Quadros ${ }^{37}$ desferindo tiro em 10 de novembro de 1937 (na época com 60 anos), João Ferreira Guimarães Barbosa, conhecido como Barbosa Paraná (que era tenente da reserva do Exército), aos 72 anos de idade, foi inocentado 12 anos e seis meses depois que ficou preso em penitenciária (cuja sentença

\footnotetext{
${ }^{37}$ A acusação de Barbosa Paraná se deu pelo fato de que Alfredo Silva, ex-marido da então companheira do dr. Miguel de Quadros, Rumilia de Quadros, teria guardado rancor devido briga ocorrida entre ambos como uma espécie de desforra, de vingança. Miguel estava em seu quintal, na manhã de 10 de novembro de 1937, alimentando a criação de aves quando levou um tiro no peito. Ficou acamado e em estado de coma, vindo a falecer no dia 12 de novembro. (DE PONTA GROSSA, 1938).
} 
Revista NEP, Núcleo de Estudos Paranaenses, Curitiba, v.4, n.2, dez. 2018

completa seria de 21 anos), pelo advogado Mario Jorge ${ }^{38}$, o qual fez a revisão do processo e comprovou efetivamente sua inocência e reabilitação total. (SERIAM INOCENTES, 1960; LIBERTADO, 1950).

Segundo o jornal A Tarde, Miguel de Quadros “(...)era, então, inimigo político do sr. Manoel Ribas, interventor no Estado [do Paraná]." (LIBERTADO, 1950). “Julgado em Ponta Grossa, Barbosa Paraná foi absolvido unanimemente. O Tribunal de Justiça do Estado, então Tribunal de Apelação, reformou a sentença e o condenou a 21 anos de prisão. Barbosa foi para a Penitenciária do Estado.” (LIBERTADO, 1950).

Ao sair da prisão, Barbosa Paraná comentou aos jornalistas do jornal A Tarde que iria realizar visita ao general Rondon, pois afirmava que eram grandes amigos na época em que tinha sido do Serviço de Proteção aos Índios. (LIBERTADO, 1950). O desenlace definitivo da questão ocorreu em 1966 quando o Estado ressarciu os herdeiros de Barbosa Paraná.

O Tribunal de Justiça pagou ontem quase dez milhões de cruzeiros aos herdeiros de João Ferreira Guimarães Barbosa, vítima de erro judiciário cometido em 1937, que o manteve encarcerado, embora inocente, por mais de doze anos. João, já falecido, foi absolvido definitivamente em 1950. Era apontado como o autor da morte do advogado Miguel Quadros. (JUDICIÁRIO, 1966).

Nos idos de 1966, o jornal Diário da Tarde ainda destaca apontamentos sobre as motivações da morte de Miguel de Quadros:

\footnotetext{
Guimarães Barbosa era apontado como o assassino do advogado Miguel de Quadro, morto com um tiro, em Ponta Grossa, em 1937. Falava-se, na época, sobre uma inimizade notória existente entre a vítima e o então interventor do Estado, Manoel Ribas, Ferreira Guimarães Barbosa, (...), em fins de 1937, foi apontado como criminoso. A imprensa de todo o país divulgou na época a sua prisão, principalmente em São Paulo, onde, um irmão da vítima, o médico Gabriel Quadros, genitor do ex-presidente Jânio Quadros promovia campanha, acusando o interventor Manoel Ribas como o mandante do crime. (RECONHECIDO, 1966).
}

38 Sobre Mario Jorge, o jornal Diário do Paraná, de 1962, menciona o seguinte aspecto: “A vida de lutas, repletas de emoções desse jovem advogado, começo, praticamente, na manhã de 10 [11] de novembro de 1937, quando foi assassinado, com um tiro de revolver, o advogado Miguel de Quadros, homicídio este ocorrido na vizinha cidade de Ponta Grossa. Naquela ocasião, após um tumultuoso inquérito policial, onde não faltaram as influências políticas e as perseguições próprias da época, foi levado, a julgamento, o cidadão João Ferreira Barbosa, que, como consequência dos desenrolar dos acontecimentos, recebeu o apelido de 'Barbosa Paraná'." (MOTORISTA, 1962). 
Revista NEP, Núcleo de Estudos Paranaenses, Curitiba, v.4, n.2, dez. 2018

O acontecimento do assassinato de Miguel de Quadros em 1937, tio de Jânio Quadro, provocou muitos debates e o desfecho comprovando a inocência de Barbosa Paraná que tinha sido declarado culpado a partir de uma série de erros e ilegalidades tornou-se conhecido em todo o Brasil. Para ilustrarmos tal questão, quando o juiz Joaquim Menelau de Almeida Torres foi declarar a inocência de Barbosa Paraná, declarando-o insuspeito por todos os jurados, a polícia entrou no recinto para prendê-los. Os homens que assistiam o julgamento tentaram segurar os policiais para que os jurados pudessem fugir pelas escadarias como o fez o advogado de Barbosa Paraná na época, porém alguns foram espancados e tiveram que fugir da cidade de Ponta Grossa. Contudo, o Tribunal de Apelação do Paraná, na figura do relator des. Antonio Leopoldo dos Santos, reformou a decisão e condenou Barbosa Paraná por 21 anos de prisão. Tais detalhes foram relatados em episódio no programa televisivo apresentado por Flávio Cavalcanti, em 1979, quando o advogado Mario Jorge recebeu homenagem por ter conseguido desvencilhar todo o ocorrido e libertar Barbosa Paraná, ainda que anos depois, de um crime que ele não tivera feito. (COMOVENTE, 1979).

Maria Dorothea Quadros Silva nasceu em 6 de abril de 1899, em São Mateus do Sul. Foi casada com dr. José Augusto da Silva, médico em Irati. Depois o casal mudouse para Curitiba, sendo conhecido como humanista clínico. Tiveram os seguintes filhos: Atys Quadros da Silva, estudante de medicina em 1942, Luiz Quadros da Silva, Clarice Quadros da Silva Novaes, Dores Quadros da Silva Wasleweski (casada com José Wasleweski) e Antonio Quadros da Silva. (ATYS, 2018). Em outra informação também consta Maria Thereza de Quadros Silva como filha de Dorothea, que se casou em 1956 com Antonio Carlos Amorim, filho de Zulmira Craveiro Amorim e de Newton Amorim, residentes em Curitiba. (ENLACE, 1956). Dorothea faleceu em 9 de julho de 1962. (DOROTHEA, 1962).

Atys, primo de Jânio, nasceu em 20 de abril de 1920, em Irati. Era patologista, formado pela Faculdade de Medicina da Universidade do Paraná. Foi professor e diretor de Hospital nos EUA. (UM MÉDICO, 1946). Em 1948 retornou ao Brasil e em 1951 montou o Laboratório de Análises Clínicas e Patologia no hospital Santa Casa de Misericórdia, além de organizar o laboratório de Anatomia Patológica do Instituto 
Revista NEP, Núcleo de Estudos Paranaenses, Curitiba, v.4, n.2, dez. 2018

Médico Legal, onde exerceu o cargo de médico até 1958, em Curitiba. (NOVA HOMENAGEM, 1978). Em 1952 prestou concurso de títulos para o cargo de médico legista do governo do estado do Paraná. (HOMOLOGADO, 1952). Retornou aos EUA no fim da década de 1950, quando assumiu o cardo de professor e patologista chefe no hospital Brackenridge, em Austin, no Texas. Em 1978 recebeu o título de "Doutor Honoris Causa" da Universidade Federal do Paraná. (NOVA HOMENAGEM, 1978). Marido de Betty Geraldine da Silva. Atys faleceu em 27 de janeiro de 1991, no estado do Texas, EUA.

João Gonçalves de Quadros, conhecido como Janguito. Pode-se dizer que é outro tio de Jânio que carrega uma história de violência e tragédia ao longo de sua vida, conforme revela Schmidt (2012). Nascido em 9 de março de 1902. Perdeu seus pais ainda criança e fora educado sobretudo pelos irmãos Maneco e Miguel, bem como de Dorothea de Quadros. Sua trajetória resume-se em entrar para colégios internos e ser expulso um a um. Dentre as revoltas e fugas dos internatos chegou a morar nas ruas por meses, cometendo pequenos delitos. Faleceu em 23 de fevereiro de 1926, aos 24 anos de idade, sendo brutalmente espancado na estação de trem Cacequi, quando viajava para Porto Alegre, Rio Grande do Sul. (SCHMIDT, 2012).

Herculano Gonçalves de Quadros, médico. Nasceu em 22 de março de 1903. Foi acadêmico da Faculdade de Medicina da Universidade do Paraná, nomeado aluno interno (plantonista noturno) no hospital da Santa Casa de Misericórdia junto com nomes de famílias importantes e futuramente com destaque na política do Paraná, tais como: Victor Ferreira do Amaral Filho, Osiris do rego Barros, Cândido Natividade da Silva, Alô Ticoulat Guimarães, Jurandir Manfredini, Domício Costa, Renato Borges de Macedo, João Oscar Espíndola, Adriano Saldanha Mazza e Telmo Antonio Borba. (AS REFORMAS, 1926).

Marília Gonçalves de Quadros Melara. Nascida em 4 de maio de 1904. Casouse em agosto de 1928 com Américo Malara, que na época era bancário. Tornou-se comerciante em Irati. Marília foi interditada aos 47 anos pelo juiz Ernani Guarita Cartaxo, a pedido de seu esposo Américo. Foi considerada incapaz de reger sua própria pessoa e administrar seus bens. Em 1929, Américo Melara era alto funcionário do Banco Frances e Italiano. (EDITAIS, 1947; AMÉRICO, 1929). Faleceu em 1952. 
Revista NEP, Núcleo de Estudos Paranaenses, Curitiba, v.4, n.2, dez. 2018

Álvaro Gonçalves de Quadros, bacharel em Direito, formado pela Universidade do Paraná, na turma de 1935. (COMEMORAÇÃO, 1945). Porém, ainda estudante, residente em Curitiba, assinou o Manifesto do PSN (Partido Social Nacionalista) como um dos membros do diretório central. (PARTIDO SOCIAL, 1934). No mesmo ano, e dias depois de ter participado da criação do partido, apresenta-se como um dos candidatos à Assembleia Legislativa do Paraná, mas não obteve votos suficientes para ser eleito. (PARTIDO SOCIAL NACIONALISTA, 1934). Álvaro casou-se com Olga Slaviero de Quadros, seus filhos Luis Gastão Slaviero de Quadros e Luis Manoel Slaviero de Quadros, gêmeos, nasceram em outubro de 1943. (NASCIMENTOS, 1943), além de João Luis Slaviero de Quadros. Luis Manoel foi candidato à vereador em Ponta Grossa, em 1963. Porém, não se sabe se disputou as eleições tendo em vista que seu nome não consta no rol de vereadores da época. Casouse com Ivone de Brito no mesmo ano. (PONTA GROSSA, 1963). Álvaro e Olga também tiveram a filha Marilene Slaviero de Quadros (NASCIMENTOS, 1943). Marilene ingressou no PTB (Partido Trabalhista Brasileiro), em Curitiba, no ano de 1981. Em 1982, foi a primeira mulher do Paraná a participar de eleições concorrendo para deputada federal (filiada ao PTB). Concorreu novamente nas eleições de 1986 para a Câmara Federal como candidata do PFL, totalizou 729 votos. (MULHERES, 1986). E, nas eleições de outubro de 1990, também disputou cadeira para deputada federal pela Coligação PRN/PFL/PDC/PSC ${ }^{39}$. Mas, neste pelito, obteve apenas 51 votos. (PRIMIERA, 1981; OS CANDIDATOS, 1990).

Olga representa uma das famílias do Paraná com grande expressão empresarial e política, além de significativas conexões via matrimônio. Descendente de Fioravante Slaviero, o patriarca da família nascido no Brasil, em 1888. A família Slaviero atua em vários ramos como hoteleiro, madeireiro, rede de concessionárias de automóveis, cartório $^{40}$, cimento, agropecuária, motores agrícolas, entre outros. $\mathrm{O}$ atual vice prefeito de Curitiba é Eduardo Slaviero Pimentel, sobrinho neto de Olga S. de Quadros. Dentre

\footnotetext{
${ }^{39}$ PRN (Partido da reconstrução Nacional - o mesmo do ex presidente Fernando Collor de Melo), PFL (Partido da Frente Liberal - cuja maior liderança era o baiano Antonio Carlos Magalhães), PDC (Partido Democrata Cristão) e PSC (Partido Social Cristão).

40 Álvaro de Quadros Neto, proprietário do cartório, do $3^{\circ}$ Serviço de Registro de Imóveis da Comarca de Ponta Grossa. (CARTÓRIOS, 2010; 2017; ÁLVARO, 2018).
} 
Revista NEP, Núcleo de Estudos Paranaenses, Curitiba, v.4, n.2, dez. 2018

as conexões familiares dos Slaviero, via casamento, temos o vínculo de parentesco com os seguintes sobrenomes do Paraná: Zagonel, Kury, Pimentel, Lunardelli, Guimarães, Ribas Carly, Gomes, Accioly, Mussi, entre outros. (GOULART, 2016).

A filha, Marilene Slaviero de Quadros foi a primeira esposa ${ }^{41}$ de José Carlos Leprevost (casaram-se em 1960 e tiveram três filhas), advogado, deputado federal pela ARENA, entre os anos 1967 a 1975 e funcionário do Tribunal de Contas do Paraná, aposentando-se em 1993. Após a aposentadoria dedicou-se ao ramo de mineração, o qual já constava como proprietários de empresas na área. José Carlos é também membro de família importante do Paraná, filho do advogado e ex prefeito de Curitiba Ney Leprevost e de Stella Surugi Leprevost. (LEPREVOST, 2018). José Carlos é tio de Ney Leprevost (neto), ex vereador, ex deputado estadual e eleito deputado federal no pleito de 2018. (MIRANDA, VALENCIANO, 2017). Josette de Quadros Leprevost, filha de Marilene e José Carlos, atualmente é funcionária da ALEP em cargo comissionado, nomeada em 11 de dezembro de 2015, processo protocolado n. 15747. (ATO, 2015). Outra filha é Maria Margarida de Quadros Leprevost, casada com Bernard Turner, em 1988.

Pelo lado materno, vale ressaltar que Jânio Quadros tem parentesco com a tradicional e família Camargo. Sua prima Lourdes, filha da tia Edwirges, chamada de Duzinha (mesmo nome de sua avó materna), veio com a família para o Paraná visitar a os parentes e numa festa levada pelo tio Gabriel Quadros (em 1930), que passou a frequentar a casa do então governador Afonso Camargo, conheceu Affonso Alves de Camargo Junior, Affonsinho. (SCHMIDT, 2012, p. 48). Jânio teve laços estreitos com o casal, pois quando vinha ao Paraná, os visitava em sua residência (na Praça Ozório), entre os anos 1950 até a década de 1980. Na sua juventude, Lourdes foi miss no Mato Grosso. (REALIZAOU, 1955; 3 JÂNIO QUADROS, 1981).

Marcílio e Marcília de Quadros, gêmeos, nascidos em outubro de 1909. Guilhermina, não resistiu às dificuldades do parto e faleceu 11 dias depois. Marcília faleceu logo após sua mãe, no dia 25 de novembro. (SCHMIDT, 2012). Em 1930 Marcílio trabalhava como secretário no departamento de criadores bovinos, da Sociedade Rural Brasileira, em São Paulo. (SOCIEDADE, 1930). Porém, Marcy, como também era chamado por seus irmãos, aos 22 anos fora assassinado em São Paulo devido uma briga

\footnotetext{
${ }^{41}$ A segunda núpcias foi com Regina Célia Gomes Guimarães Leprevost. (LEPREVOST, 2018).
} 
Revista NEP, Núcleo de Estudos Paranaenses, Curitiba, v.4, n.2, dez. 2018

por conta de dívida de aluguel que envolvia a família de sua namorada e, portanto, era inocente na referida questão. Após entender que o conflito entre os envolvidos havia acabado, Marcy aparece no local de discussão e recebe um tiro na testa e cai morto. Foi assassinado pelo filho do dono da casa alugada, um menino de 16 anos, que se entregou na companhia de seu pai. O fato, ocorrido no dia 5 de fevereiro de 1932, tornou-se notícia em vários jornais de São Paulo.

A família Quadros é significativamente extensa e suas raízes se firmaram entre os estados de São Paulo e do Sul do Brasil. Sendo assim, podemos apontar alguns Quadros que tiveram conexões e casamentos com Paranaenses ainda no século XIX, embora muito se tenha para averiguar em relação aos aspectos genealógicos e conexões entre os referidos troncos familiares. Nessa perspectiva, segundo Miguel Arnildo Gomes (2014), em $O$ guerreiro e a mulher, podemos citar os referidos Quadros:

- Bernardo Antonio Quadros, nascimento provável em 1830, Ponta Grossa. Filho de Joaquim Manoel de Quadros e Pulcéria Borges de Quadros, descendentes em terceiro grau de Antonio de Quadros Bicudo (nascido em Itu, SP) e de Antonia Pereira (nascida em Curitiba), casaram-se em 1742, ambos falecidos em Castro, na fazenda Carambeí. Bernardo casou-se com com Felicidade maria Xavier, nascida em 1841 em Curitiba (filha de Francisco Xavier de Castro, nascido no Rio Grande do Sul em 1809, e de Ana Joaquina Ferreira, nascida em Castro, no ano de 1820 e falecida no Rio Grande do Sul em 1871). Bernardo e Felicidade mudaram-se para o rio Grande do Sul em 1856. Filhos de Bernardo e Felicidade: Maria de Jesus de Quadros, nascida em dezembro de 1856 e falecida em 1876; Bernardinno de Quadros, nascido em 24 de maio de 1858; Bernardinha Xavier de Quadros; Dinarte Pereira de Quadros; Manoel Francisco Xavier de Quadros, nascido em 24 de dezembro de 1863, na estância Bom Retiro; João Bernardo de Quadros (mestiço), filho de Bernardo com escravizada Catita; Simplício, adotado, foi retirado da senzala por ter sofrido paralisia infantil. Bernardo participou da Guerra do Paraguai.

- Firmino Pereira de Queiroz casado com Galdina Honorata de Quadros, filha de Francisco Leandro de Quadros e Balbina Maria da Trindade de Quadros. A filha do casal, Polsina de Quadros casou-se com seu primo Manoel Francisco (Sinhozinho). Outra filha, 
Revista NEP, Núcleo de Estudos Paranaenses, Curitiba, v.4, n.2, dez. 2018

Marcolina, casou-se com o major Francisco Marques Xavier.Firmino e Galdina foram proprietários da fazenda São Miguel, em São Bento (RS) e tiveram vasta família.

- Pedro Bueno de Quadros, casado com Ana Maria de Quadros, filha de Bernardo Pereira de Quadros e de Ana Cláudia Martins. Foram proprietários da fazenda Invernada do Posto de Vista Alegre. Assim como o trisavô de Jânio, Joaquim José de Quadros, Pedro lutou na Guerra do Paraguai e chegou ao posto de capitão.

No que diz respeito aos descendentes dos Quadros que encontramos nomeados em secretarias de governo (Secretaria dos Negócios do Interior, Justiça e Instrução Pública) entre os anos 1928 a 1930: Catharian de Quadros Souza, praticante da Diretoria Geral de Ensino (1928); Leontina Quadros Souza, normalista, professora do grupo escolar professor Cleto, na capital (1928); professora Corintha B. Quadros, grupo escolar Telêmaco Borba, em Tibagy (1928); Juliana de Quadros, professora na localidade estiva, em Serro Azul (1928); professoras Ignez Quadros e professora Maria Elisa Quadros, no grupo escolar Jesuíno Marcondes, em Palmeira (1928). ${ }^{42}$

\section{Considerações Finais}

Os Quadros representam genealogicamente mais uma típica família dos grupos superiores, bons casamentos, bem educados, com cursos superiores desde o início do século XX e com boas posições na sociedade ao longo dos séculos XIX e XX, sempre bem inseridos no Estado, ainda que não alcançando os grandes poderes e altos cargos regionais, todavia, sempre estiveram bem posicionados na classe dominante, tipo "baixa classe alta", ou "periferia da classe dominante tradicional", mas dentro do "status quo dominante" e ao longo de várias gerações, o que também pode ser percebido pelos casamentos.

Talvez o tronco desta família Quadros no Sul do Brasil, no século XVIII, esteja aqui - "Aos dezoito de Dezembro do ano de mil e setecentos e oitenta e nove faleceu da

\footnotetext{
42 Arquivo Público do Estado do Paraná. Relatórios de Secretários de Governo. Disponível em: 〈http://www.arquivopublico.pr.gov.br/modules/conteudo/conteudo.php?conteudo=59>. Acesso em: $02 / 11 / 2018$
} 
vida presente Xisto de Quadros de Araujo, Alferes das Ordenanças de idade de cinquenta anos mais ou menos, Viúvo" "43. E que passaria como hipótese para um Xisto de Quadros Bicudo, 2-4 na Genealogia Paulistana ${ }^{44}$, uma condição social e genealógica da família Quadros no Litoral de Santa Catarina e na Antiga Capitania de São Paulo, inserida na periferia da "pequena nobreza da terra" desde o período colonial, o que mostra a longa continuidade de vantagens, privilégios, patentes, matrimônios, capitais sociais, educacionais e políticos dos seus membros. O "ethos cultural", o habitus de classe" da família, a relação com a violência, as bruscas mudanças, a passionalidade, a inconstância, a mobilidade, a polêmica, os humores, os estilos, como valores sociais, também podem ser percebidos ao longo das várias gerações.

\section{Referências}

A EQuitativa. Commércio do Paraná, Curitiba, 23 jan. 1925. Disponível em: <http://memoria.bn.br/DocReader/DocReader.aspx?bib=765309\&pesq=francisco\%20bu rzio >. Acesso em: 08/12/2018.

A UNIVERSIDADE e a primeira turma de juristas. Diário do Paraná, Curitiba, 17 dez. 1972.

Disponível

em:

<http://memoria.bn.br/DocReader/DocReader.aspx?bib=761672\&PagFis=89963\&Pesq $=$ luiz $\% 20$ gonzaga\%20de\%20quadros $>$. Acesso em: 18/11/1072.

ADVOGADOS. Almanach do Paraná. 1929. Disponível em: <http://memoria.bn.br/DocReader/DocReader.aspx?bib=214752\&pesq=luiz\%20gonzag a\%20de\%20quadros $>$. Acesso em: 19/11/2018.

ADMINISTRAÇÃO. Almanak Laemmert, Rio de Janeiro, 1935. Disponível em: < $<$ http://memoria.bn.br/DocReader/Hotpage/HotpageBN.aspx?bib=313394\&pagfis=116 341\&url=http://memoria.bn.br/docreader\#>. Acesso em: 02/12/2018.

AGRADECIMENTO. Diário da Tarde, Curitiba, 24 jun. 1910. Disponível em: <http://memoria.bn.br/DocReader/DocReader.aspx?bib=800074\&pesq=maria\%20clara \%20de\%20siqueira>. Acesso em: 14/10/2018.

43

$<$ http://www.mafra.com.br/genealogia/getperson.php?personID=I018974\&tree=arfamis001 $>$. Acesso em: $18 / 11 / 2018$

${ }^{44}$ Disponível em: <http://www.arvore.net.br/Paulistana/Quadros.htm>. Acesso em: 18/11/2018. 
Revista NEP, Núcleo de Estudos Paranaenses, Curitiba, v.4, n.2, dez. 2018

AGRADECIMENTOS. Diário da Tarde, Curitiba, 15 nov. 1913. Disponível em: <http://memoria.bn.br/DocReader/DocReader.aspx?bib=800074\&pesq=jo\%C3\%A3o\% 20manoel\%20de\%20quadros >. Acesso em: 25/11/2018.

ALISTAMENTO Eleitoral. O Paranaense, Curitiba, 9 jul. 1881. Disponível em: $<$ http://memoria.bn.br/DocReader/DocReader.aspx?bib=248261\&pesq=jo\%C3\%A3o\% 20manoel\%20de\%20quadros>. Acesso em: 25/11/2018.

ÁLVARO de Quadros Neto, tabelião em Ponta Grossa. Br - Tabeliãos.com. Disponível em: 〈http://br-tabeliaes.com/diretorio/alvaro-de-quadros-neto>. Acesso em: 25/11/2018.

ALVES, Alessandro Cavassin. A Província do Paraná e sua Assembleia Legislativa (1853-1889). A força política das famílias tradicionais. Curitiba: Máquina de Escrever, 2015 .

AMÉRICO Melara. A República, Curitiba, 21 fev. 1929. Disponível em: $<$ http://memoria.bn.br/DocReader/DocReader.aspx ?bib=215554\&pesq=am\%C3\%A9ric o\%20melara>. Acesso em: 09/12/2018.

ANIVERSÁRIO da S.S.N. Diário do Paraná, Curitiba, 20 set. 1981. Disponível em: <http://memoria.bn.br/DocReader/DocReader.aspx?bib=761672\&pesq=joaquim\%20ma noel\%20de\%20Quadros>. Acesso em: 24/11/2018.

AO COMÉRCIO. Diário da Tarde, Curitiba, 20 fev. 1909. Disponível em: <http://memoria.bn.br/DocReader/DocReader.aspx?bib=800074\&pesq=jo \%C3\%A3o\% 20manoel\%20de\%20quadros>. Acesso em: 25/11/2018.

AS REFORMAS do Hospital da Santa Casa de Misericórdia. O Estado do Paraná, Curitiba, 1 out. $1926 . \quad$ Disponível em: <https://docs.google.com/document/d/1f6fWMyDrwp2vV2joznMhfdbGbznYk_iDJI8W Ue1IYHA/edit>. Acesso em: 24/11/2018.

ATAQUE ao dr. Alencar Guimarães - Artigo do acadêmico Miguel Quadros. Diário da Tarde. Curitiba, 9 fev. 1910. Disponível em: <http://memoria.bn.br/DocReader/DocReader.aspx ?bib=800074\&PagFis=4916\&Pesq= miguel\%20de\%20quadros >. Acesso em: 21/10/2018.

ATO da Comissão Executiva No 2489/2015. Diário Oficial do Estado do Paraná. Disponível em: <https://www.escavador.com/diarios/322181/DOEPR/diario-oficial-daassembleia/2015-12-

15?page $=15 \&$ fbclid=IwAR0plk8NYRW4ShY5dpCXVlmnWP2hzuNbmOBMjARafqE NkcmDaHJOb1RsYMA>. Acesso em: 25/11/2018.

ATYS Quadros da Silva. Disponível em: <https://www.geni.com/people/Atys-QuadrosDa-Silva-MD/6000000035989791396>. Acesso em: 25/11/2018. 
Revista NEP, Núcleo de Estudos Paranaenses, Curitiba, v.4, n.2, dez. 2018

BATISTELLA, Alessandro. O Partido Trabalhista no Paraná (1945-1965). Curitiba: Editora UFPR, 2017.

BENEVIDES, Maria Victória de Mesquita. O governo Jânio Quadros. São Paulo: Brasiliense, 1981.

BRANCO, Carlos Castello. A renúncia de Jânio: um depoimento. Rio de Janeiro: revan, 1996.

CANDIDATURA. Sete de Março, Curitiba, 29 ago. 1888. Disponível em: $<$ http://memoria.bn.br/DocReader/DocReader.aspx bib=812870\&pesq=jo\%C3\%A3o\% 20manoel\%20de\%20quadros>. Acesso em: 25/11/2018.

CARTÓRIOS: de quem são? (ou eram?). 2010. Disponível em: <http://cartorios.blogspot.com/2010/07/alvaro-quadros-neto-tentando-dar-uma.html >.

Acesso em: 25/11/2018.

CARTÓRIOS: de quem são? (ou eram?) 2017. Disponível em: <http://cartorios.blogspot.com/2017/08/por-que-alvaro-de-quadros-neto.html>. Acesso em: $25 / 11 / 2018$.

CASAMENTO. Enlace Pinheiro Lima - Cavalcanti de Quadros. Correio do Paraná, Curitiba, 20 fev. $1942 . \quad$ disponível em: <http://memoria.bn.br/DocReader/DocReader.aspx?bib=171395\&pesq=scharffenberg>. Acesso em: 17/11/2018.

CASAMENTO CIVIL. A República, Curitiba, 10 nov. 1905. Disponível em: <http://memoria.bn.br/DocReader/DocReader.aspx?bib=215554\&pesq=scharffenberg $>$. Acesso em: 17/11/2018.

CASAMENTOS. Correio do Paraná. Curitiba, 10 jul. 1937. Disponível em: $<$ http://memoria.bn.br/DocReader/DocReader.aspx? bib=171395\&PagFis=7405\&Pesq= miguel\%20de\%20quadros $>$. Acesso em: 14/10/2018.

CATANI, Afrânio Mendes; NOGUEIRA, Maria Alice; HEY, Ana Paula; MEDEIROS, Cristina Carta Cardoso de Medeiros. (Orgs.). Vocabulário Bourdieu. Belo Horizonte: Autêntica Editora, 2017.

CENTRO Cultural Scharffenberg de Quadros. Última Hora, Curitiba, 13 jun. 1918. Disponível em: <http://memoria.bn.br/DocReader/DocReader.aspx?bib=830348\&pesq=scharffenberg $>$. Acesso em: 17/11/2018.

COLONO espancado. Diário da Tarde, Curitiba, 23 fev. 1907. Disponível em: <http://memoria.bn.br/DocReader/DocReader.aspx?bib=800074\&pesq=luiz\%20gonzag a\%20de\%20quadros\&pasta=ano\%20190>. Acesso em: 25/11/2018. 
Revista NEP, Núcleo de Estudos Paranaenses, Curitiba, v.4, n.2, dez. 2018

CHAIA, Vera. A liderança política de Jânio Quadros (1947-1990). São Paulo: Humanidades, 1991.

COMEMORAÇÃO do $10^{\circ}$ aniversário de formatura dos bacharéis de 1935. Diário do

Paraná. Curitiba, 11 dez. 1945. Disponível em: <http://memoria.bn.br/DocReader/DocReader.aspx ?bib=171433\&pesq=\%C3\%A1lvaro \%20gon\%C3\%A7alves\%20de\%20Quadros>. Acesso em: 24/11/2018.

COMOVENTE homenagem de Flávio Cavalcanti a reparador de erro judiciário. Diário do Paraná, Curitiba, $1^{\circ}$ abr. $1979 . \quad$ Disponível em: <http://memoria.bn.br/DocReader/DocReader.aspx?bib=761672\&pesq=miguel\%20de\% 20quadros >. Acesso em: 09/12/2018.

COMUNICAÇÕES e convites. O Olho da Rua. Curitiba, 10 jul. 1911. Disponível em: $<$ http://memoria.bn.br/DocReader/DocReader.aspx ?bib=240818\&pesq=miguel $\% 20 \mathrm{de} \%$ 20\%20quadros>. Acesso em: 13/10/2018.

CONTRATOS de casamento. A República, Curitiba, 27 set. 1912, p.2. Disponível em: <http://memoria.bn.br/DocReader/DocReader.aspx ?bib=215554\&PagFis=26214\&Pesq $=$ maria\%20julia\%20de\%20quadros $>$. Acesso em: 03/12/2018.

DATAS Intimas. Diário da Tarde. Curitiba, 22 maio 1930. Disponível em: <http://memoria.bn.br/DocReader/DocReader.aspx?bib=800074\&pesq=dirce $\% 20 q u a d r$ os>. Acesso em: 16/11/2018.

DE PONTA GROSSA - Esclarecido e mistério. Correio do Paraná. Curitiba, 5 ago. $1938 . \quad$ Disponível em: <http://memoria.bn.br/DocReader/DocReader.aspx?bib=171395\&PagFis=7405\&Pesq= miguel\%20de\%20quadros>. Acesso em: 15 out. 1938.

DOROTHEA Quadros da Silva. Diário do Paraná, Curitiba, 13 jul. 1962. Disponível em:

<http://memoria.bn.br/DocReader/DocReader.aspx?bib=761672\&pesq=dorothea\%20qu adros\%20silva>. Acesso em: 25/11/2018.

DR. MIGUEL Quadros. O Estado. Curitiba, 13 nov. 1937. Disponível em: <http://memoria.bn.br/DocReader/DocReader.aspx bib $=830275 \&$ PagFis=2275\&Pesq= miguel\%20de\%20quadros >. Acesso em: 14/10/2018.

DR. PAMPHILO d'Assumpção. Diário da Tarde, Curitiba, 18 set. 1909. Disponível em: <http://memoria.bn.br/DocReader/DocReader.aspx?bib=800074\&PagFis=9049\&Pesq=1 uiz\%20gonzaga\%20de\%20quadros>. Acesso em: 19/11/2018.

DRS. MARCELliNO Nogueira Junior. Diário da Tarde, Curitiba, 25 mar. 1918. Disponível

em: 
NE P Revista NEP, Núcleo de Estudos Paranaenses, Curitiba, v.4, n.2, dez. 2018

<http://memoria.bn.br/DocReader/DocReader.aspx?bib=800074\&PagFis=23999\&Pesq =luiz\%20gonzaga\%20de\%20quadros>. Acesso em: 19/11/2018.

EDITAL DE CITAÇÃO para conhecimento dos herdeiros de dona Dorothea Quadros Silva, viúva do dr. José Augusto da Silva, com prazo de 30 dias. Diário da Tarde. Curitiba, 15 mar. $1963 . \quad$ Disponível em: <http://memoria.bn.br/DocReader/DocReader.aspx?bib=800074\&PagFis=12417\&Pesq $=$ miguel $\% 20 \mathrm{de} \% 20$ quadros $>$. Acesso em: 21/10/2018.

EDITAIS judiciais. Diário do Paraná, Curitiba, 19 abr. 1947. Disponível em: $<$ http://memoria.bn.br/DocReader/DocReader.aspx?bib=171433\&pesq=am\%C3\%A9ric o\%20melara>. Acesso em: 09/12/2018.

ENFERMO. O Estado do Paraná, Curitiba, 12 nov. 1925. Disponível em: $<$ http://memoria.bn.br/DocReader/DocReader.aspx?bib=830372\&pesq=francisco $\% 20 \mathrm{bu}$ rzio >. Acesso em: 08/12/2018.

ENLACE. Diário do Paraná, Curitiba, 30 ago. 1956. disponível em: <http://memoria.bn.br/DocReader/DocReader.aspx?bib=761672\&pesq=dorothea\%20qu adros\%20silva>. Acesso em: 25/11/2018.

ENLACE Quadros-Lange. O Estado. Curitiba, 9 jul. 1937. Disponível em: $<$ http://memoria.bn.br/DocReader/DocReader.aspx?bib=830275\&pesq=miguel $\% 20 \mathrm{de} \%$ 20quadros >. Acesso em: 14/10/2018.

ENLACE MIRANDA-SILVA. Correio do Paraná, Curitiba, 9 out. 1937. Disponível em:

$<$ http://memoria.bn.br/DocReader/DocReader.aspx?bib=171395\&pesq=Manoel\%20Jos \%C3\%A9\%20de\%20Miranda>. Acesso em: 02/12/2018.

ENTRE o céu e a terra. O Dia, Curitiba, 29 jun. 1929. Disponível em: < http://memoria.bn.br/DocReader/DocReader.aspx?bib=092932\&pesq=scharffenberg > .

Acesso em: 17/11/2018.

ESCRITÓRIO de Advocacia. Diário da Tarde. Curitiba, 6 abr. 1936. Disponível em: $<$ http://memoria.bn.br/DocReader/DocReader.aspx?bib=800074\&PagFis=12417\&Pesq $=$ miguel $\% 20 \mathrm{de} \% 20$ quadros $>$. Acesso em: 21/10/2018.

ESPANCAMENTO. A Notícia, Curitiba, 28 fev. 1907. Disponível em: <http://memoria.bn.br/DocReader/DocReader.aspx?bib=187666\&pesq=luiz\%20gonzag a\%20de\%20quadros\&pasta=ano\%20190>. Acesso em: 20/11/2018.

FALECIMENTO: Sra. Carolina Lupion. Diário da Tarde, Curitiba, 16 fev. 1952. Disponível em:

http://memoria.bn.br/DocReader/DocReader.aspx?bib=800074\&pesq=Maria\%20de\%20 Jesus\%20Lupion\%20de\%20Quadros>. Acesso em: 17/11/2018. 
Revista NEP, Núcleo de Estudos Paranaenses, Curitiba, v.4, n.2, dez. 2018

FALECIMENTOS. Diário do Paraná, Curitiba, 14 jul. 1946. Disponível em: <http://memoria.bn.br/DocReader/DocReader.aspx?bib=171433\&pesq=miguel $\% 20 \mathrm{de} \%$ 20\%20quadros >. Acesso em: 13/10/2018.

FALECIMENTOS MANOEL Joaquim de Quadros. O Estado do Paraná. Curitiba, 5 dez. $1926 . \quad$ Disponível em: <http://memoria.bn.br/DocReader/DocReader.aspx?bib=830372\&pesq=miguel $\% 20 \mathrm{de} \%$ 20\%20quadros>. Acesso em: 13/10/2018.

FATOS Diversos. Diário da Tarde, Curitiba, 6 ago. 1903. Disponível em: <http://memoria.bn.br/DocReader/DocReader.aspx?bib=800074\&pesq=jo\%C3\%A3o\% 20manoel\%20de\%20quadros $>$. Acesso em: 25//1/2018.

FERREIRA, Ezilda; DUARTE, Valter. A renúncia de Jânio Quadros: componentes históricos e institucionais. Curitiba: CRV, 2011.

GOMES, Miguel Arnildo. O guerreiro e a menina mulher. Contos e Histórias do Vô Miguel. 7 out. 2014. Disponível em: <https://vovomiguel.blogspot.com/2014/10/historiao-guerreiro-e-menina-

mulher.html?fbclid=IwAR1u51KT6lmUvTKHbQc_8eZdgs0s_ixoJAGWrEFK3RvtZFP

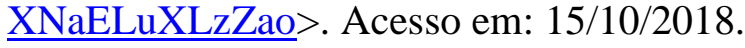

GOULART, Mônica Helena Harrich S. A Dança das Cadeiras. Análise do jogo político na Assembleia Legislativa do Paraná. Jundiaí: Paco Editorial, 2014.

Família Slaviero: uma história de grandes conquistas. Revista NEP - Núcleo de Estudos Paranaenses, v. n. 2, 2016.

GUARDA Nacional. A República, Curitiba. 29 abr. 1907. Disponível em: <http://memoria.bn.br/DocReader/DocReader.aspx?bib=215554\&pesq=sebasti\%C3\%A 30\%20augusto\%20de\%20Quadros>. Acesso em: 24/11/1907.

HOMOLOGADO pelo secretário de governo o concurso de títulos, para a carreira de médico legista. Diário da Tarde, Curitiba, 19 maio 1952. Disponível em: < http://memoria.bn.br/DocReader/DocReader.aspx?bib=800074\&pesq=atys \%20quadros \%20da\%20silva>. Acesso em: 30/11/2018.

JÂNIO Quadros. FGV-CPDOC. Disponível em: 〈https://cpdoc.fgv.br/producao/dossies/Jango/biografias/janio_quadros's. Acesso em: $11 / 10 / 2018$.

3 JANIO QUADROS. Diário do Paraná, 8 jul. 1981, p. 8, $2^{\circ}$ cad. Disponível em: $<$ http://memoria.bn.br/DocReader/DocReader.aspx ?bib=761672\&PagFis=6335\&Pesq=1 ourdes\%20\%20camargo >. Acesso em: 01/12/2018. 
Revista NEP, Núcleo de Estudos Paranaenses, Curitiba, v.4, n.2, dez. 2018

JOÃO QUADROS. Árvores Genealógicas MyHeritage. Disponível em: <https://www.myheritage.com.br/names/jo\%C3\%A3o_quadros?fbclid=IwAR11RWEh NrEWMuUdlfqFLpkDcT_MkOgh12nv4YSXCio17qveh3FX_FyK2X0>. Acesso em: 26/11/2018.

JUDICIÁRIO erra e paga. Diário do Paraná. Curitiba, 29 jun. 1966. Disponível em: <http://memoria.bn.br/DocReader/DocReader.aspx?bib=761672\&pesq=miguel $\% 20 \mathrm{de} \%$ 20quadros>. Acesso em: 14/10/2018.

JUNTA Municipal de Qualificação. A Regeneração, Santa Catarina, Cidade do desterro, $1^{\circ}$ dez. $1878 . \quad$ Disponível em: <http://memoria.bn.br/DocReader/DocReader.aspx?bib=709603\&pesq=joaquim\%20jos \%C3\%A9\%20de\%20quadros >. Acesso em: 02/12/2018.

LEPREVOST. CPDOC-FGV. Verbete José Carlos Leprevost. Disponível em: $\langle$ http://www.fgv.br/cpdoc/acervo/dicionarios/verbete-biografico/leprevost-jose-carlos $>$. Acesso em: 25/11/2018.

LIBERTADO depois de 12 anos e meio de reclusão. A Tarde. Curitiba, 4 jul. 1950. Disponível em: <http://memoria.bn.br/DocReader/docreader.aspx?bib=797596\&pesq=4\%20julho\%20d e\%201950>. Acesso em: 20/10/2018.

MEMORANDUM eleitoral. A República, Curitiba, 11 ago. 1899. Disponível em: $<$ http://memoria.bn.br/DocReader/DocReader.aspx?bib=215554\&pesq=ernesto\%20gui mar\%C3\%A3es\%20vilella>. Acesso em: 08/12/2018.

MIRANDA, Eduardo Soncino; VALENCIANO, Tiago. O poder das famílias nas eleições de 2016 no Paraná: como e por quê parentes e política se perpetuam no estado? Revista NEP - Núcleo de Estudos Paranaenses, Curitiba, v.3, n. 3, p. 156-174, ago. 2017.

MISSA. A República. Curitiba, 7 nov. 1913. Disponível em: <http://memoria.bn.br/DocReader/DocReader.aspx?bib=215554\&pesq=gabriel\%20nog ueira\%20de\%20quadros>. Acesso em: 12/10/2018.

MISSA de primeiro aniversário. O Dia, Curitiba, 10 out. 1954. Disponível em: <http://memoria.bn.br/DocReader/DocReader.aspx?bib=092932\&pesq=Antonio\%20Sc harffenberg\%20de\%20Quadros >. Acesso em: 11/11/2018.

MOTORISTA Assassinado em Ponta Grossa foi a causa de grave erro judiciário. Diário do Paraná. Curitiba, 10 ago. 1962. Disponível em: <http://memoria.bn.br/DocReader/DocReader.aspx?bib=761672\&pesq=miguel $\% 20 \mathrm{de} \%$ 20quadros >. Acesso em: 14/10/2018.

MULHERES com poucos votos. Correio de Notícias, Curitiba, 2 dez. 1986. Disponível em: 
NE P Revista NEP, Núcleo de Estudos Paranaenses, Curitiba, v.4, n.2, dez. 2018

$<\underline{\text { http://memoria.bn.br/DocReader/DocReader.aspx } ? \text { bib=325538_01\&pesq=slaviero\%20 }}$ de\%20quadros $>$. Acesso em: 10/12/2018.

MUNICÍPIO DE POLONI. Câmara Municipal de Poloni. Os eleitos do IV Centenário. Disponível em: $<$ http://camarapoloni.sp.gov.br/Uploads/Arquivos/Os_eleitos_do_IV_Centenario.pdf?fb clid=IwAR3bx7qpYCufn4hdoltHJWxXZCposH3vN0M8U6ZKjYNZIgt2eBY1Wnv5_Y>. Acesso em: 12/10/2018.

NASCIMENTOS. Diário da Tarde, Curitiba, 20 out. 1943. Disponível em: <http://memoria.bn.br/DocReader/DocReader.aspx?bib=092932\&pesq=\%C3\%A1lvaro \%20gon\%C3\%A7alves\%20de\%20Quadros>. Acesso em: 25/11/2018.

NOIVADOS. Correio do Paraná, Curitiba, 25 mar. 1937. Disponível em: 〈http://memoria.bn.br/DocReader/DocReader.aspx?bib=171395\&pesq=scharffenberg >. Acesso em: 17/11/2018.

NOTAS \& Notícias. A República, Curitiba, 5 jun. 1922. Disponível em: <http://memoria.bn.br/DocReader/DocReader.aspx?bib=215554\&pesq=sebasti\%C3\%A 3o\%20augusto\%20de\%20Quadros >. Acesso em:24/11/2018.

NOTAS Sociais. O Estado do Paraná. Curitiba, Disponível em: $<$ http://memoria.bn.br/DocReader/DocReader.aspx?bib=830372\&pesq=gabriel\%20nog ueira\%20de\%20quadros>. Acesso em: 13/10/2018.

NOTICIÁRIO. Dezenove de Dezembro, Curitiba, 16 jan. 1869. Disponível em: 〈http://memoria.bn.br/DocReader/DocReader.aspx?bib=416398\&pesq=joaquim\%20jos \%C3\%A9\%20de\%20quadros >. Acesso em: 02/11/2018.

NOTICIÁRIO. Diário da Tarde, Curitiba, 18 ago. 1915. Disponível em: $<$ http://memoria.bn.br/DocReader/DocReader.aspx?bib=800074\&PagFis=9049\&Pesq=1 uiz\%20gonzaga\%20de\%20quadros >. Acesso em: 19/11/2018.

NOVA HOMENAGEM para professor. Diário da Tarde, Curitiba, 11 abr. 1978. Disponível em:

http://memoria.bn.br/DocReader/DocReader.aspx?bib=800074\&pesq=atys \%20quadros \%20da\%20silva>. Acesso em: 30/11/2018.

O CANCELAMENTO de uma pena disciplinar. Comércio do Paraná. Curitiba, 13 de junho de 1923.1 Disponível: <http://memoria.bn.br/DocReader/DocReader.aspx ?bib=765309\&PagFis=1781\&Pesq= miguel\%20de\%20\%20quadros >. Acesso em: 14/10/2018.

O LAMENTÁVEL incidente de Ponta Grossa. Correio do Paraná, Curitiba, 15 out. 1935. 
Revista NEP, Núcleo de Estudos Paranaenses, Curitiba, v.4, n.2, dez. 2018

$<$ http://memoria.bn.br/DocReader/docreader.aspx?bib=171395\&pesq=15\%20outubro\% 20de\%201935\%20o\%20lament\%C3\%A1vel\%20incidente>. Acesso em: 15/10/2018.

O MOVIMENTO editorial de Gerpa. O Dia, Curitiba, 3 abr. 1945. Disponível em: <http://memoria.bn.br/DocReader/DocReader.aspx?bib=092932\&PagFis=39977\&Pesq =scharffenberg $>$. Acesso em: 17/11/2018.

O POEMA Dos 18 do Forte. Diário da Tarde, Curitiba, 2 ago. 1957. Disponível em: <http://memoria.bn.br/DocReader/DocReader.aspx?bib=800074\&pesq=scharffenberg $>$. Acesso em: 17/11/2018.

O POETA Schafferberg de Quadros vai ser homenageado em seu torrão natal. Diário da Tarde, Curitiba, 30 out. 1939. Disponível em: <http://memoria.bn.br/DocReader/DocReader.aspx?bib=800074\&pesq=scharffenberg $>$. Acesso em: 17/11/2018.

OS BACHAREL[sic] ano 1917. Diário da Tarde, Curitiba, 10 nov. 1917. Disponível em:

<http://memoria.bn.br/DocReader/DocReader.aspx?bib=800074\&PagFis=23495\&Pesq =luiz\%20gonzaga\%20de\%20quadros >. Acesso em: 19/11/2018.

OS CANDIDATOS à Câmara Federal. Correio de Notícias, Curitiba, 11 out. 1990. Disponível em: <http://memoria.bn.br/DocReader/DocReader.aspx?bib=325538_02\&pesq=slaviero\%20 de\%20quadros >. Acesso em: 10/12/1990.

OS DETRATORES da minha honra. A República. Curitiba, 29 out. 1919. Disponível em:

<http://memoria.bn.br/DocReader/DocReader.aspx?bib=215554\&pesq=miguel $\% 20 \mathrm{de} \%$ 20quadros >. Acesso em: 20/10/2018.

OS QUE NASCEM. O Dia, Curitiba, 10 fev. 1931. Disponível em: <http://memoria.bn.br/DocReader/DocReader.aspx?bib=092932\&pesq=scharffenberg $>$. Acesso em: 17/11/2018.

OS QUE MORREM. A República, Curitiba, 3 nov. 1913. Disponível em: <http://memoria.bn.br/DocReader/DocReader.aspx?bib=215554\&PagFis=22486\&Pesq $=\mathrm{jo} \% \mathrm{C} 3 \% \mathrm{~A} 3 \mathrm{o} \% 20 \mathrm{manoel} \% 20 \mathrm{de} \% 20$ quadros $>$. Acesso em: 26/11/2018.

PÁGINA do Partido Social Nacionalista. Diário da Tarde, Curitiba, 4 set. 1934. Disponível em: <http://memoria.bn.br/DocReader/DocReader.aspx?bib=800074\&PagFis=23999\&Pesq =luiz\%20gonzaga\%20de\%20quadros >. Acesso em: 19/11/2018. 
Revista NEP, Núcleo de Estudos Paranaenses, Curitiba, v.4, n.2, dez. 2018

PARTIDO Social Nacionalista. Diário da Tarde, Curitiba, 29 set. 1934. disponível em: <http://memoria.bn.br/DocReader/DocReader.aspx $? \mathrm{bib}=800074 \&$ PagFis=23999\&Pesq =luiz\%20gonzaga\%20de\%20quadros $>$. Acesso em: 19/11/2018.

PARTIDO SOCIAL Nacionalista. Diário da Tarde, Curitiba, 2 out. 1934. Disponível em:

<http://memoria.bn.br/DocReader/DocReader.aspx ?bib=800074\&PagFis=27925\&Pesq $=\%$ C $3 \%$ A1lvaro\%20gon\%C3\%A7alves\%20de\%20Quadros $>$. Acesso em: 25/11/2018.

PARTIDO SOCIAL NACIONALISTA. Diário da Tarde, Curitiba, 10 out. 1934. Disponível em: $<$ http://memoria.bn.br/DocReader/DocReader.aspx?bib=800074\&PagFis=27925\&Pesq $=\%$ C $3 \%$ A1lvaro $\% 20$ gon $\%$ C3\%A7alves \%20de\%20Quadros $>$. Acesso em: 25/11/2018.

PASSADOS IMPERFEITOS. Disponível em: <https://passadoimperfeito.weebly.com/joaquim.html>. Acesso em: 10/10/2018.

PASSAMENTO. A República, Curitiba, 27 out. 1909. Disponível em: <http://memoria.bn.br/DocReader/DocReader.aspx? bib=215554\&PagFis=21628\&Pesq =jo\%C3\%A3o\%20manoel\%20de\%20quadros $>$. Acesso em: 26/11/2018.

PELA POLÍTICA. O Estado do Paraná, Curitiba, 16 jan. 2018. Disponível em: <http://memoria.bn.br/DocReader/DocReader.aspx bib=811688\&pesq=sebasti\%C3\%A 3o\%20augusto\%20de\%20Quadros>. Acesso em: 24/11/2018.

PERSEGUIÇÃO. A República, Curitiba, 21 out. 1899. Disponível em: <http://memoria.bn.br/DocReader/DocReader.aspx?bib=215554\&pesq=jo\%C3\%A30\% 20manoel\%20de\%20quadros>. Acesso em: 26/11/2018.

PONTA GROSSA. Última Hora, Curitiba, 21 jan. 1963. Disponível em: <http://memoria.bn.br/DocReader/DocReader.aspx?bib=830348\&pesq=slaviero\%20de \%20quadros>. Acesso em: 10/12/2018.

PRIMEIRA fase de filiação encerrada. Diário da Tarde, Curitiba, 16 nov. 1981. Disponível em: <http://memoria.bn.br/DocReader/DocReader.aspx?bib=800074\&pesq=slaviero $\% 20 \mathrm{de}$ \%20quadros>. Acesso em: 10/12/2018.

PROTESTO. Diário da Tarde, Curitiba, 14 nov. 1910. Disponível em: <http://memoria.bn.br/DocReader/DocReader.aspx?bib=800074\&pesq=sebasti\%C3\%A 3o\%20augusto\%20de\%20Quadros>. Acesso em: 24/11/2018.

OLIVEIRA, Ricardo Costa de. (Org.). Família importa e explica: Instituições políticas e parentesco no Brasil. São Paulo: LiberArs, 2018. 
Revista NEP, Núcleo de Estudos Paranaenses, Curitiba, v.4, n.2, dez. 2018

Na teia do nepotismo: Sociologia Política das relações de parentesco e poder político no Paraná e no Brasil. Curitiba: Insight, 2012.

O silêncio dos vencedores: genealogia, classe dominante e estado no Paraná. Curitiba: Moinho do Verbo, 2001.

OLIVEIRA, Ricardo Costa de. MONTEIRO, José Marciano; GOULART, Mônica H. H. S; VANALI, Ana C. Família, parentesco, instituições e poder no Brasil: retomada e atualização de uma agenda de pesquisa. Revista Brasileira de Sociologia, v. 5, n. 11, set/dez. 2017.

QUADROS, Scharffenberg de. Os 18 do Forte. Curitiba: Edição de GERPA (Grupo editor Renascimento do Paraná), 1954.

REALIZOU visitas. Diário do Paraná, Curitiba, 19 jun. 1955. Acesso em: $<$ http://memoria.bn.br/DocReader/DocReader.aspx?bib=761672\&pesq=lourdes $\% 20 \% 2$ 0camargo >. Acesso em: 01/12/2018.

RECONHECIDO erro judiciário cometido em 1937. Diário do Paraná. Curitiba, 29 jun. 1966. Disponível em: $<$ http://memoria.bn.br/DocReader/DocReader.aspx ?bib=761672\&PagFis=58759\&Pesq $=$ miguel $\% 20 \mathrm{de} \% 20$ quadros $>$. Acesso em: 14/10/2018.

REGISTRO Civil. A República, Curitiba, 13 jun. 1908. Disponível em: <http://memoria.bn.br/DocReader/DocReader.aspx?bib=215554\&pesq=scharffenberg $>$. Acesso em: 17/11/2018.

REGISTRO de Diploma. Diário da Tarde. Curitiba, 31 jan. 1927. Disponível em: <http://memoria.bn.br/DocReader/DocReader.aspx?bib=800074\&pesq=gabriel\%20nog ueira\%20de\%20quadros>. Acesso em: 12/10/2018.

RESPONDENDO a um vil e a um irresponsável. Comércio do Paraná, Curitiba, 29 maio $1923 . \quad$ Disponível em: <http://memoria.bn.br/DocReader/DocReader.aspx?bib=765309\&PagFis=1732\&Pesq= sebasti\%C3\%A3o\%20augusto\%20de\%20Quadros>. Acesso em: 24/11/2018.

RIO. Dezesseis de Julho. Rio de Janeiro, 18 mar. 1870. Disponível em: $<$ http://memoria.bn.br/DocReader/DocReader.aspx?bib=766194\&pesq=miguel $\% 20 \mathrm{de} \%$ 20\%20quadros >. Acesso em: 13/10/2018.

RIO CLARO. A República, Curitiba, 31 maio 1902. Disponível em: $<$ http://memoria.bn.br/DocReader/DocReader.aspx? $\mathrm{bib}=215554 \&$ pesq=jo $\% \mathrm{C} 3 \% \mathrm{~A} 30 \%$ 20manoel\%20de\%20quadros >. Acesso em: 26/11/2018.

RIO CLARO. A República, Curitiba, 29 jul. 1907. Disponível em: <http://memoria.bn.br/DocReader/DocReader.aspx?bib=215554\&pesq=joaquim\%20ma noel\%20de\%20Quadros >. Acesso em: 24/11/2018. 
Revista NEP, Núcleo de Estudos Paranaenses, Curitiba, v.4, n.2, dez. 2018

RODRIGUES Dalledone. Correio do Paraná, Curitiba, 18 jun. 1942. Disponível em: $<$ http://memoria.bn.br/DocReader/DocReader.aspx?bib=171395\&pesq=rumilia\%20de\% 20almeida\%20quadros>. Acesso em: 08/12/2018.

SCHMIDT, Bernardo. Jânio: vida e morte do homem da renúncia. V.I. Um moço bem velhinho. São Paulo: O Patativa, 2012.

SECÇÃO Alheia. Diário da Tarde, Curitiba, 24 jan. 1901. Disponível em: $<$ http://memoria.bn.br/DocReader/DocReader.aspx bib=800074\&PagFis=2119\&Pesq=1 uiz\%20gonzaga\%20de\%20quadros>. Acesso em: 19/11/2018.

SENHORINHA Dirce Quadros. Diário da Tarde. Curitiba, 26 nov. 1934. Disponível em:

$<$ http://memoria.bn.br/DocReader/DocReader.aspx ?bib=800074\&pesq=dirce $\% 20 q u a d r$ os>. Acesso em: 16 nov. 2018.

SERIAM INOCENTES os três condenados de Ponta Grossa. Última Hora. Curitiba, 2 jun. $1960 . \quad$ Disponível em: <http://memoria.bn.br/DocReader/DocReader.aspx ?bib=830348\&pesq=miguel $\% 20 \mathrm{de} \%$ 20\%20quadros>. Acesso em: 13/10/2018.

SOCIEDADE rural brasileira. Correio Paulistano, São Paulo, 24 jan. 1930. Disponível em:

<http://memoria.bn.br/DocReader/DocReader.aspx?bib=090972_08\&pesq=marc\%C3\% ADlio\%20de\%20quadros>. Acesso em: 09/12/2018.

SOUZA, Jessé. A elite do atraso: da escravidão à Lava Jato. Rio de Janeiro: Leya, 2017.

A tolice da inteligência brasileira: ou como o país se deixa manipular pela elite. Rio de Janeiro: Leya, 2015.

TESOURO Provincial. Província do Paraná, Curitiba, 21 jun. 1879. Disponível em: <http://memoria.bn.br/DocReader/DocReader.aspx?bib=704768\&pesq=jo\%C3\%A3o\% 20manoel\%20de\%20quadros>. Acesso em: 25/11/2018. .

TRIUNPHO. A República, Curitiba, 15 abr. 1905. Disponível em: <http://memoria.bn.br/DocReader/DocReader.aspx?bib=215554\&PagFis=11746\&Pesq =luiz\%20gonzaga\%20de >. Acesso em: 19/11/2018.

ÚLTIMAS Notícias. A República. Curitiba, 18 fev. 1915. Disponível em: $<$ http://memoria.bn.br/DocReader/DocReader.aspx?bib=215554\&pesq=miguel $\% 20 \mathrm{de} \%$ 20quadros >. Acesso em: 20/10/2018.

UM MÉDICO paranaense nos E.E. U. U. Diário do Paraná, Curitiba, 9 nov. 1946. Disponível

em: 
$<$ http://memoria.bn.br/DocReader/DocReader.aspx ?bib=171433\&pesq=atys\%20quadro s\%20da\%20silva $>$. Acesso em: 29/11/2018.

UMA VILA operária em Ponta Grossa. O Estado do Paraná. Curitiba, 8 set. 1926. Disponível <http://memoria.bn.br/DocReader/DocReader.aspx?bib=830372\&pesq=miguel\%20de\% 20\%20quadros>. Acesso em: 13/10/2018.

UNIÃO Democrática Nacional. Diário do Paraná, Curitiba, 29 set. 1947. Disponível em: $<$ http://memoria.bn.br/DocReader/DocReader.aspx?bib=171433\&pesq=jos\%C3\%A 9\%20pedro\%20da\%20silva\%20carvalho>. Acesso em:08/12/2018.

VIDA Social. Comércio do Paraná. Curitiba, 30 de agosto de 1922. Disponível em: $<$ http://memoria.bn.br/DocReader/DocReader.aspx?bib=765309\&pesq=miguel $\% 20 \mathrm{de} \%$ 20\%20quadros >. Acesso em: 14/10/2018.

VOTO de pesar. Diário do Paraná, Curitiba, 23 maio 1956. Disponível em: <http://memoria.bn.br/DocReader/DocReader.aspx?bib=761672\&pesq=sebasti\%C3\%A 3o\%20augusto\%20de\%20Quadros>. Acesso em: 24/11/2018.

VULTOS PARANAENSES. Diário do Paraná, Curitiba, 17 mar. 1957. Disponível em: <http://memoria.bn.br/DocReader/DocReader.aspx?bib=761672\&pesq=Antonio\%20Sc harffenberg\%20de\%20Quadros>. Acesso em: 17/11/2018.

WITTIG, Ehrenfried Othmar. Gabriel Quadros você não conhece, mas seu filho com certeza. Museu de História da Medicina. Disponível em: <http://www.crmpr.org.br/publicacoes/cientificas/index.php/revista-do-medicoresidente/article/viewFile/99/106>. Acesso em: 16 nov. 2018.

Recebido: 10 nov. 2018

Aceito: 05 dez. 2018 